\title{
Predictive Model for Archeological and Historic Site Locations Within the Big Fossil Creek Drainage, Tarrant County, Texas
}

\author{
Nancy Parrish \\ Geo-Marine, Inc. \\ Elizabeth A. Burson \\ Geo-Marine, Inc.
}

Follow this and additional works at: https://scholarworks.sfasu.edu/ita

Part of the American Material Culture Commons, Archaeological Anthropology Commons, Environmental Studies Commons, Other American Studies Commons, Other Arts and Humanities Commons, Other History of Art, Architecture, and Archaeology Commons, and the United States History Commons

Tell us how this article helped you.

This Article is brought to you for free and open access by the Center for Regional Heritage Research at SFA ScholarWorks. It has been accepted for inclusion in Index of Texas Archaeology: Open Access Gray Literature from the Lone Star State by an authorized editor of SFA ScholarWorks. For more information, please contact cdsscholarworks@sfasu.edu. 
Predictive Model for Archeological and Historic Site Locations Within the Big Fossil Creek Drainage, Tarrant County, Texas

\section{Creative Commons License}

\section{(c) (1) $\Theta(9$}

This work is licensed under a Creative Commons Attribution-NonCommercial-No Derivative Works 4.0 International License. 


\title{
PREDICTIVE MODEL FOR ARCHEOLOGICAL AND HISTORIC SITE LOCATIONS WITHIN THE BIG FOSSIL CREEK DRAINAGE, TARRANT COUNTY, TEXAS
}

\author{
by \\ Nancy A. Parrish \\ Elizabeth A. Burson \\ Principal Investigator \\ Duane E. Peter \\ for \\ U.S. Army Corps of Engineers \\ Fort Worth District \\ 819 Taylor Street \\ Fort Worth, Texas 76102
}

Contract Number DACA63-99-D-0010

Task Order 0038

MisCELLANEOUS REPORTS OF INVESTIGATIONS

NUMBER 250

Geo-Marine, Inc.

550 East 15th Street

Plano, Texas 75074

August 2002 


\section{CONTRACT DATA}

This document was prepared under Contract Number DACA63-99-D-0010, Task Order Number 0038 (GMI Project No. 10100.00.38), with the U.S. Army Corps of Engineers, Fort Worth District, 819 Taylor Street, Fort Worth, Texas 76102. 


\section{EXECUTIVE SUMMARY}

The U.S. Army Corps of Engineers (USACE), Fort Worth District, is investigating the water resource problems, needs, and opportunities within the Big Fossil Creek drainage in Tarrant County, Texas. The effort focuses on describing existing conditions and identifying measures to minimize and control flood loss within a 48,396.8-acre area of the drainage north of the city of Fort Worth. Geo-Marine, Inc., of Plano, Texas, was contracted by the USACE to assess the potential for historic properties within the drainage area. Background research and a pedestrian reconnaissance survey of the project area were carried out and a geographical information systems (GIS) model was designed to evaluate the probability for both surface and subsurface cultural resources deposits within the project area and to make recommendations for further treatment of any properties.

The field reconnaissance carried out between November 21 and December 5, 2001, revealed that the project area has been subject to severe impact and alteration through modern development and construction. Observed creek cut banks showed intact stratigraphic deposits in areas where the creek bank or course had not been altered by construction or channelization. The results of research, field observation, and GIS models were analyzed to create a predictive model for site potential within the Big Fossil Creek drainage. Future archeological survey should be limited to undisturbed cut banks in the eastern half of the drainage. In the southeastern portion of the drainage, near the confluence of Big Fossil Creek and the West Fork of the Trinity River, backhoe trenching in flood plain areas along with intensive cut bank survey is recommended to locate deeply buried deposits. No future archeological survey is recommended west of Interstate 35 , in the upland prairie region of the drainage. Examination of archival data indicated that the potential for historic buildings adjacent to the channel is extremely limited. 


\section{TABLE OF CONTENTS}

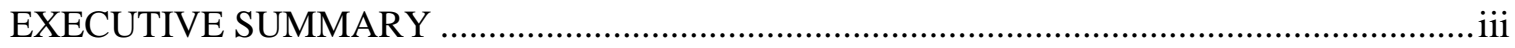

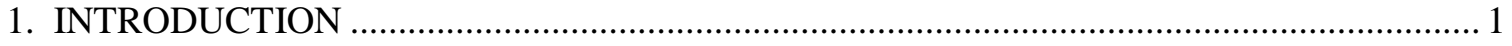

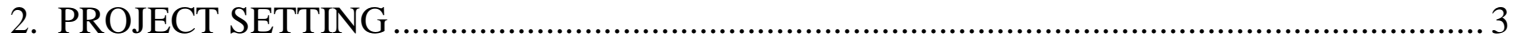

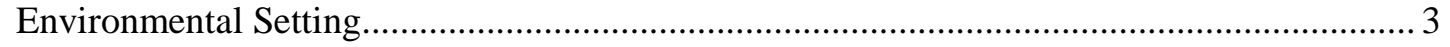

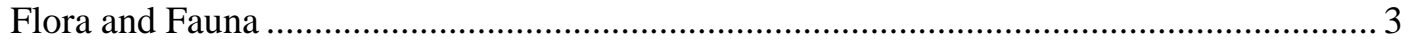

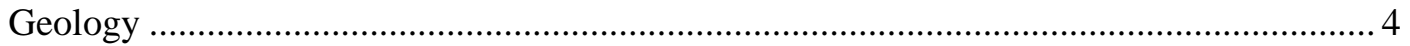

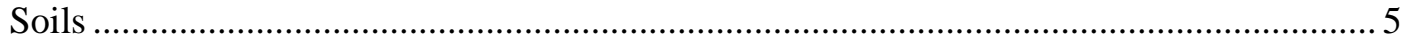

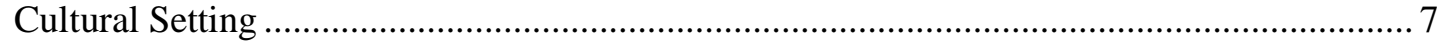

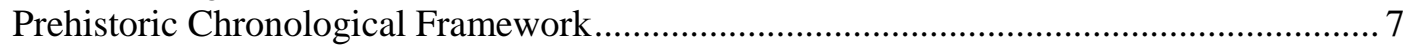

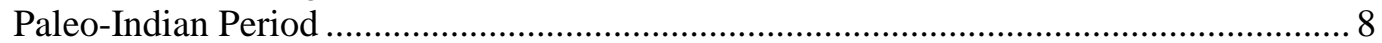

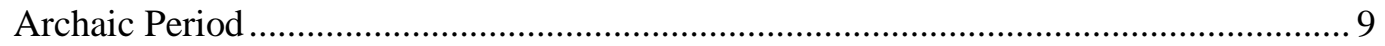

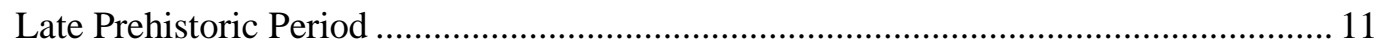

Historic Indian Period..................................................................................................... 13

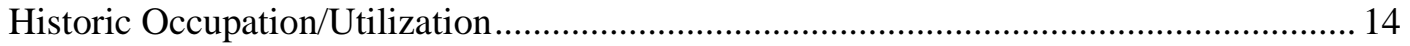

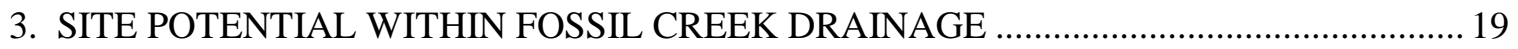

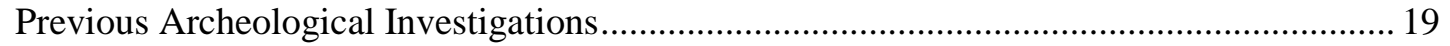

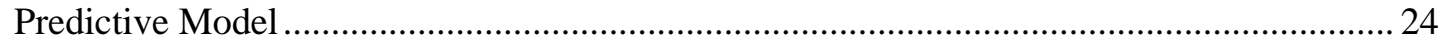

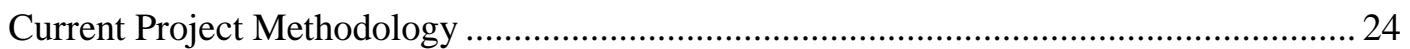

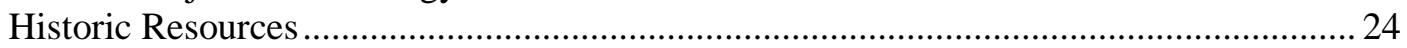

Site Potential/Recommendations for Future Work ....................................................... 28

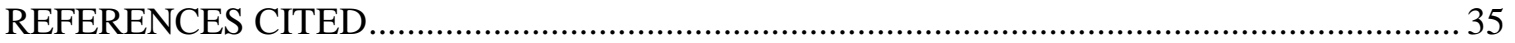




\section{LIST OF FIGURES}

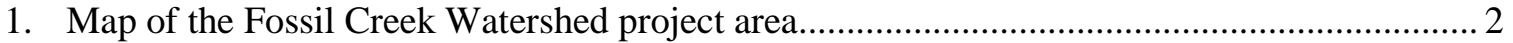

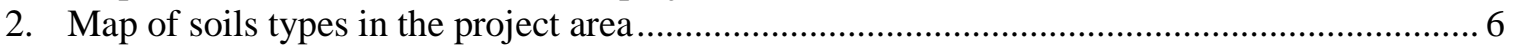

3. Maps of Birdville: (a) location on the 1855 Tarrant County Land Grant Office map; and (b) 1851 Plat Map

4. Previously surveyed areas and location of historic Birdville settlement................................ 21

5. View of development along channelized bank of Big Fossil Creek........................................ 25

6. View of undeveloped tract along Big Fossil Creek showing erosion...................................... 25

7. Borrow pit near the confluence of Big Fossil Creek and Trinity River with Austin

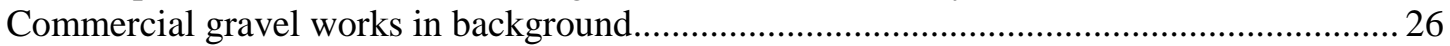

8. View of empty lot in abandoned gravel quarry; Big Fossil Creek drainage beyond

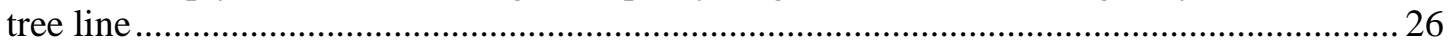

9. View of construction on the flood plain of Big Fossil Creek east of Blue Mound Road........ 27

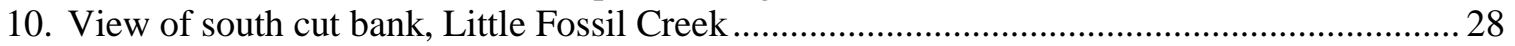

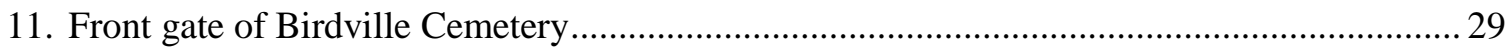

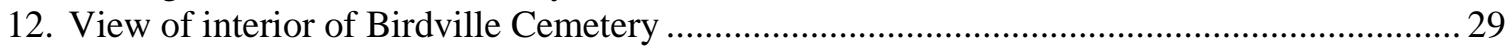

13. Map showing the potential for intact prehistoric cultural resources....................................... 31

14. Areas of potential architectural significance within project area ......................................... 33 


\section{LIST OF TABLES}

1. Native American Chronology for the Upper Trinity River Basin............................................. 8 


\section{CHAPTER 1 INTRODUCTION}

The U.S. Army Corps of Engineers (USACE), Fort Worth District, is investigating the water resource problems, needs, and opportunities within the Big Fossil Creek drainage in Tarrant County, Texas. The effort focuses on describing existing conditions and identifying measures to minimize and control flood loss within a 48,396.8-acre area of the drainage north of the city of Fort Worth (Figure 1). Current federal mandates require cultural resources investigations to meet legal responsibilities for the identification, evaluation, and treatment of historic properties when initiating a Federal undertaking within the drainage. These mandates include those from Section 106 of the National Historic Preservation Act (NHPA) and the National Environmental Policy Act of 1969. Geo-Marine, Inc. (GMI), of Plano, Texas, was contracted by the USACE to assess the potential for historic properties within the drainage area. Background research and a pedestrian reconnaissance survey of the project area were carried out and a geographical information systems (GIS) model was designed to evaluate the probability for both surface and subsurface cultural resources deposits within the project area and to make recommendations for further treatment of any properties.

A literature and archival search was conducted to determine if any recorded sites are located within the project area. Site records from the Texas Archeological Research Laboratory (TARL) at the University of Texas at Austin were consulted. Soil survey maps prepared by the U.S. Soil Conservation Service and aerial photographs were also consulted extensively. Field reconnaissance was conducted between November 21 and December 5, 2001, by Duane Peter, Michelle Wurtz, and Nancy Parrish of GMI. Duane Peter also served as Principal Investigator. The following report presents an analysis of archeological site potential in the Big Fossil Creek drainage area. Chapter 2 provides an environmental and cultural setting for the project area. Chapter 3 is a discussion of previous archeological investigations in the region and sites that have been recorded within the project area. The chapter concludes with a predictive model for site potential within the drainage and recommendations for future treatment with regard to archeological site location within the drainage. 
Predictive Model for Archeological and Historic Site Locations: Big Fossil Creek Drainage, Tarrant County, Texas

\section{figure}

1. Map of the Fossil Creek Watershed project area 


\section{CHAPTER 2 PROJECT SETTING}

\section{ENVIRONMENTAL SETTING}

Environmentally, the upper Trinity River basin includes three physiographic zones. Moving from east to west, these zones are the Trinity River Floodplain Forest, the Eastern Cross Timbers, and the Grand Prairie (see Yates and Ferring 1986:12-31 for a treatment of the environment of the upper Trinity basin). The project area is located predominately in the Grand Prairie, which is characterized by black, calcareous clay soils and by a dominance of grasses, with shrubs and trees present along stream bottoms and flood plains. The eastern edge of the project area falls within the Eastern Cross Timbers region, a north-south-trending zone of scrub oak woodland that coincides with a band of sandy soil. The understory of the Cross Timbers is essentially the same as the prairie vegetation, but the sandier soils permit a dense upper story of scrub oak to thrive in the uplands (McMahan et al. 1984). The southern tip of the project area, at the confluence of Big Fossil Creek and the West Fork of the Trinity River, extends into the Trinity River Floodplain Forest zone.

The entire upper Trinity River basin, including the project area, falls within Blair's (1950:100102) Texan biotic province. Yates and Ferring (1986:22) point out that the Texan province is not so much a distinct geographic unit as it is a giant ecotone in which species from both the east and the west overlap at the limits of their ranges. Species composition and forest density varies greatly between the Grand Prairie, Eastern Cross Timers, and Trinity River Floodplain Forest. For prehistoric hunter/gatherers, the potential for each zone to provide exploitable floral and faunal resources would have been different from zone to zone.

\section{Flora and Fauna}

The Grand Prairie, which covers the majority of the Big Fossil Creek drainage, contained small, widely scattered trees. Tall grasses and forbs were the dominant vegetation in the prairies. While many of the species growing in the prairie could have provided nutritious nuts and fruits for human and deer populations, the density of these foods was too low to have been a significant resource for human subsistence. Larger mammals, such as pronghorn and, later, bison, may have browsed the prairies, but in low numbers and with intermittent frequency. Exploitation of such herds would have been opportunistic, at best, for prehistoric hunters making the Grand Prairie among the least important ecological zones to prehistoric populations. 
The Eastern Cross Timbers, which span the southeastern portion of the drainage area, was a distinctive forest type comprised of mast-producing trees traversing the Grand Prairie. Although fewer in number, the trees in the Cross Timbers would have produced more per tree than in the forest proper due to the lack of competition between trees and the ample room for canopy development. Oak would have dominated this zone producing acorns; a major source of carbohydrates for human populations in the early autumn. Oak is also a primary feed for wild turkey and deer, therefore, the Cross Timbers would have been a desirable environment for these game. The undergrowth of berries and grasses would have provided a variety of microhabitats of exploitable floral and faunal resources for early hunter/gatherers.

The Upper Trinity River Floodplain Forest consists of the flood plain forest and the bottomland prairie and occurs where the Eastern Cross Timbers bisects the flood plain. The southeastern most tip of the Big Fossil Creek Drainage area falls into this zone, where Big Fossil Creek empties into the West Fork of the Trinity River. The bottom prairie often contained lakes and was subject to seasonal overflow where surface water was retained. The vegetation of these pockets of prairie was primarily grasses and few trees, similar to the Grand Prairie. The flood plain forests contain a large and diverse range of tree species. The forest produced rich nuts and fruits in abundance as well as providing an attractive habitat for a variety of game animals. In addition to the large numbers of mammals and birds attracted to it, the riverine flood plain area was also a source of fish, turtles, water fowl, and shellfish for prehistoric peoples.

The resources in the Eastern Cross Timbers and the Trinity Floodplain Forest would have been the most reliable and abundant source of sustenance for hunter/gatherers with a variety of foodstuffs available in these zones during spring, summer, and fall. The Grand Prairie would have supported occasional herds of large mammals opportunistically hunted for protein and fat. Complete listings of the faunal resources of the upper Trinity River basin can be found elsewhere (Yates and Ferring 1986:12-31), but the region as a whole is characterized by a high species diversity (Yates and Ferring 1986:22) corresponding to the variety of ecotones. Despite the presence of large mammal prairie species, such as buffalo and pronghorn, faunal remains recovered from archeological contexts indicate that deer, found predominately in the Crass Timbers and Trinity River Floodplain Forest zones, was the primary source of meat protein throughout the prehistoric period (Yates and Ferring 1986:27).

\section{Geology}

The near-surface geology of the project area consists of Quaternary-age gravels, sands, silts, and clays unconformably overlying limestones, marls, and shales of Lower Cretaceous age. The creek bed and flood plain consist of Pleistocene fluviatile terrace deposits and Holocene alluvium. The dominant Lower Cretaceous units present are: a portion of the Pawpaw Formation, Weno Limestone, and Denton Clay. The southwestern boundary of the project area is underlain by the Fort Worth Limestone and Duck Creek formations. These two groups both consist of a series of fossiliferous, shallow-water marine limestones and shales that is less than 85 meters (m) in thickness. Grayson Marl and limes and shales of the Main Street Limestone-part of the Lower Cretaceous units-have been found along the northeastern edge of the project area. All of these units dip gently eastward into the East Texas Basin and all have been subjected to considerable erosional sculpting (Barnes 1988). During the extended period of erosion between the Cretaceous and the present, the more erosion-resistant limestones of this sedimentary package probably served to inhibit valley widening and formed topographic benches and knolls within the flood plain itself. 


\section{Soils}

Soils in the Big Fossil Creek drainage project area are mapped by the U.S. Soil Conservation Service as dominated by the Sanger-Purves-Slidell association (Ressel 1981). Soils in this association are on uplands and are primarily well-drained soils that have a slope of 0-5 percent. The association is comprised of approximately 28 percent Sanger soils, 15 percent Purves soils, and 10 percent Slidell soils. Forty-seven percent of the association is made up of less extensive areas of Aledo, Bolar, Frio, Lindale, Mingo, and San Saba soils, and Urban Land. The eastern and northeastern edge of the project area fall within the Ponders-Sanger-Slidell association and the urbanized southeastern tip of the project area consists of both the Frio-Trinity and BastsilSilawa associations.

Some 59 individual soil map units are found within the project area, along with areas mapped as Urban land, pits and quarries, and water (Figure 2). Of these, Sanger clays 1 to 3 percent slope and 3 to 5 percent slope dominate, covering 29.1 percent $(14,095.12$ acres) of the total area. Sanger clay, 1 to 3 percent slopes, is deep, well-drained, gently sloping clayey soil in valley fill areas between limestone ridges. In generalized profile, Sanger clay has a 20 inch surface layer that begins as very dark grayish brown clay grading to dark grayish brown in the lower part. Beneath this, from 20 to 49 inches in depth, is grayish brown silty clay underlain by 31 inches of light yellowish brown silty clay that has common masses of calcium carbonate and limestone fragments and pebbles (Ressel 1981:47). Sanger clay, 3 to 5 percent slopes, is a deep, well drained, gently sloping clayey soil found in valley fill areas and on side slopes of ridges below limestone outcrops. Typically, the surface layer is 46 inches of calcareous clay that is dark grayish brown in the upper part and light grayish brown in the lower part. Underlying this is yellowish and brownish shaly clay to a depth of 63 inches (Ressel 1981:48).

Slidell clay, 1 to 3 percent slopes, is the next most prevalent soil map unit, covering 10.5 percent (5,091.56 acres) of the project area. Slidell clay, 1 to 3 percent slopes, is deep, gently sloping clayey soil in valley fill areas along drainageways. The surface layer is generally very dark gray clay to 22 inches below surface. From 22 to 70 inches in depth, lies dark gray clay grading to grayish brown with depth. Underlying this, to a depth of 80 inches, is light brownish gray silty clay with yellowish mottles and masses and concentrations of calcium carbonate (Ressel 1981:52).

Aledo gravelly clay loam, 1 to 8 percent slopes, covers 7.8 percent (3,753.07 acres) of the total project area. This soil is a well-drained shallow to very shallow, gently sloping to sloping loamy soil along ridgetops. The typical profile for Aledo gravelly clay loam consists of brown gravelly clay loam 0 to 7 inches below surface, underlain by brown very gravelly clay loam that contains about 60 percent limestone fragments. Below that, to a depth of 24 inches, lies coarsely fractured limestone (Ressel 1981:13).

Purves clay, 0 to 3 percent slopes, covers 7.2 percent (3,484.02 acres) of the project area. Purves clay, 0 to 3 percent slopes, is well drained, shallow, nearly level to gently sloping, clay soil on ridgetops. A typical profile consists of dark grayish brown clay to a depth of 7 inches overlying 7 to 15 inches of brown clay. Beneath this is fractured limestone interbedded with clayey marl (Ressel 1981:45). 
Predictive Model for Archeological and Historic Site Locations: Big Fossil Creek Drainage, Tarrant County, Texas

\section{Figure}

2. Map of soils types in the project area 
Some 23.9 percent (11,566.85 acres) of the area is described as Urban land complex with a variety of base soil associations (includes 20 different map units). Urban land is defined by Ressel (1981:57) as 85 to 100 percent works and structures such as offices, dwellings, sidewalks, schools, parking lots, shopping centers, and the like, that have altered or that obscure soils beyond identification. A variety of Urban land complexes is concentrated in the southern end and southeastern edge of the project area. Urban land has also been mapped along the southwestern edge of the project boundary, and pockets of developed Urban property exist throughout the project area. Water, pits and quarries, and two units of Arents soils comprised of overburden and fill from gravel and sand mining, comprise a total of 2 percent (967 acres) of the total project area.

The remaining soil units identified in the project area each cover less than 3 percent (less than 1,500 acres per map unit) of the project area. Figure 2 shows the complex distribution of soil types in the project area. Sixty two percent (20 individual map units) of the remaining soil types (13.3 percent of the project area; 6,475.5 acres) are described as clay or clay loam. Silty clay (Frio silty clay, frequently and Frio silty clay, occasionally flooded) line the stream channel and flood plains and make up 4.2 percent (2,027.01 acres) of the total project area. Eleven fine sandy loam soil map units together comprise less than 2 percent (less than 967 acres) of the total project area. These areas form pockets primarily along the eastern edge of the project area and along ridge tops to the northeast.

\section{CULTURAL SETTING}

\section{Prehistoric Chronological Framework}

Despite a long history of archeological research in Northcentral Texas and the southern plains (Jelks 1967; Krieger 1946, 1947; Prewitt 1981, 1985), as well as several recent summary overviews (Hofman et al. 1989; Prikryl 1990; Story et al. 1990; Vehik 1994), the chronological framework for the upper Trinity River basin is not well developed. The available data allow the delineation of only a generalized chronology. Investigations at Joe Pool Lake (Peter and McGregor 1988) provided evidence for a refinement of the chronology for the Late Prehistoric period, although the overall regional applicability of the phases recognized there are still in some dispute. Prikryl (1990) presented a chronological sequence of six periods, but he relied almost entirely on diagnostic artifacts from surface contexts and comparisons to dated contexts distant from the upper Trinity River basin. Despite this, chronological data from recent excavations at Ray Roberts Lake and Lewisville Lake reportedly conform well to his suggested sequence (Ferring and Yates 1997, 1998).

The chronology presented here (Table 1) is taken from the introduction to the regional preservation plan for the Prairie-Savanna Archeological Region, of which the upper Trinity River basin is a part (Prikryl 1993). A brief summary of the adaptations and archeological remains associated with these periods is presented below. 
Table 1

Native American Chronology for the Upper Trinity River Basin

(after Prikryl 1993)

Temporal Periods and Subdivisions

Paleo-Indian Period

Archaic Period

$$
\begin{aligned}
& \text { Early } \\
& \text { Middle } \\
& \text { Late }
\end{aligned}
$$

Late Prehistoric Period

$$
\text { I }
$$$$
\text { II }
$$

Years B.C./A.D.

9950-6500 B.C.

6500-4000 B.C. 4000-1500 B.C. 1500 B.C.- A.D. 700

A.D. $700-1200$

A.D. $1200-1700$

A.D. $1700-1850$

\section{Paleo-Indian Period}

The Paleo-Indian period in Northcentral Texas (ca. 9950-6500 B.C.) generally includes those remains of human presence that can be dated to the very late Pleistocene and the immediate postPleistocene periods (for recent reviews relevant to this period in Northcentral Texas, see Hofman 1989a; Johnson 1989; Prikryl 1990; and Story 1990). Unfortunately, the Paleo-Indian occupation of the upper Trinity River basin is known primarily through diagnostic projectile points from surface collections or from stratigraphically mixed contexts (Meltzer 1987; Meltzer and Bever 1995). The Field Ranch site (41CO10) along the upper Elm Fork is a prime example of typical site contexts (Jensen 1968). Based on a sample of projectile points from surface sites, Prikryl (1990) has suggested that the most common Paleo-Indian point types in this area are Plainview and Dalton. Ferring and Yates (1997) suggest that these types date to about 9,500-10,000 years ago, based on cross dating with other regions. The suggested age for these types may correspond with the onset of early Holocene alluviation in the Trinity River valley.

Clovis and Plainview points are commonly found along both Denton and Clear creeks in the Cross Timbers, northwest of Dallas. Until recently, the Lewisville Lake site (41DN71) was the best known Paleo-Indian site within the region, containing large burned features interpreted as hearths, and a low density of artifacts, including a Clovis point (Crook and Harris 1957, 1958, 1961). Although the original radiocarbon dates on the hearths suggested an anomalously early age for Clovis points (ca. 37,000 B.P.), more recent work by the Smithsonian Institution (Stanford 1981) appears to have resolved the controversy concerning the date of the occupation there. It appears that the presence of naturally-occurring lignite in these hearths, either as a fuel or as an inadvertent inclusion, contaminated the radiocarbon samples. Consequently, the usually accepted date of 12,000-10,000 B.P. for Clovis period occupations is probably a reasonable estimate for the first human occupation of Northcentral Texas. 
A more spectacular exception to the generally limited data on Paleo-Indian sites in Northcentral Texas is the deeply buried Clovis-age Aubrey site (41DN479), located on the Elm Fork of the Trinity River north of Dallas (Ferring 1989, 2001). The discovery of this site, buried approximately 7-8 m below the top of the Elm Fork flood plain just below the Lake Ray Roberts dam, suggests that well-preserved Paleo-Indian sites in Northcentral Texas will only be found by examining deeply stratified Holocene alluvium in modern flood plain situations.

Despite the lack of extensive data relating to the early Paleo-Indian period in Northcentral Texas, some attempts have been made to generalize regarding settlement mobility and intensity of site occupation, drawing on what is known and on assumptions based on comparisons with other areas. For instance, a number of researchers have seen evidence for a high degree of group mobility in the broad distribution of Paleo-Indian artifacts over the landscape and in the variety of presumably non-local lithic raw materials from which the artifacts were made (Meltzer and Smith 1986; Shafer 1977; Story 1990:177). Likewise, the well-documented exploitation of megafauna by Paleo-Indians in the western United States, coupled with the known presence of similar animals in Northcentral Texas between 11,000 and 9,000 years ago (see Slaughter and Hoover 1963), has resulted in the popular (and logical) conclusion that big game hunting was part of the Paleo-Indian subsistence strategy in Northcentral Texas. However, the recent important excavations at the Aubrey site have indicated that subsistence efforts did not focus on big game animals alone. Rather, the entire range of prairie and forest species was used by the occupants of the site, including bison, deer, rabbits, squirrels, fish, and abundant turtle (Ferring 1989; Ferring and Yates 1997). Interestingly, although mammoth remains are present, their exploitation has not been substantiated (Ferring and Yates 1997). Whether this pattern of a more generalized foraging subsistence system is characteristic of Clovis adaptations on the fringes of the Eastern Woodlands and the focus on now extinct, big game species is more characteristic of a Plains adaptation remains to be documented; but Ferring and Yates (1997:5) suggest that, in general, the Clovis people probably employed "very flexible adaptive strategies."

\section{Archaic Period}

The Archaic period in Northcentral Texas is tentatively dated between 6500 B.C. and A.D. 700 . As is true for many areas, a threefold division of the Archaic period, consisting of early, middle, and late subdivisions, has been applied in Northcentral Texas (Prikryl 1990, 1993). Thus, the Early Archaic has been dated from 6500 to 4000 B.C., the Middle Archaic from 4000 to 1500 B.C., and the Late Archaic from 1500 B.C. to A.D. 700. Relatively recent overviews that cover the Archaic in this portion of Texas include Hofman (1989a), Prikryl (1990), and Story (1985, 1990). Archaic remains are usually found in upland settings and are frequently mixed with later material. In fact, the initial treatment of the Archaic period in Northcentral Texas (Crook and Harris 1952, 1954), which defined the Carrollton and Elam foci, was based upon materials from such mixed terrace contexts. Consequently, these time-space constructs are no longer recognized as being acceptable for this area of Texas (Peter and McGregor 1988; Prikryl 1990; Yates and Ferring 1986). General trends that have been proposed as characterizing the Archaic period in Northcentral Texas include an increasing complexity of settlement systems, increasing population size and density, decreasing mobility, and the development of distinct group territories (Prikryl 1990; Story 1985:52). 
During the Early Archaic (ca. 6500-4000 B.C.), in general, the occurrence of small and widely distributed sites has been suggested to reflect high group mobility within large and poorly defined territories, with a generalized hunting and gathering economy (Meltzer and Smith 1986; Story 1985:35, 39). Unfortunately, Early Archaic occupations in Northcentral Texas are poorly documented and no sites with isolable Early Archaic components in this area are known (Prikryl 1990). Based on surface collections, Prikryl (1990) hypothesizes a generalized hunting-andgathering economy during this period, with high group mobility, a lack of regionalization, and "little in the way of recognized territorial boundaries" (Prikryl 1990:71). Projectile point forms that may be associated with the Early Archaic in Northcentral Texas include Early Split Stemmed and possibly Angostura (Prikryl 1990; Story 1990:Figure 31). In comparison to the Early Archaic, the Middle Archaic period in Northcentral Texas (4000-1500 B.C.) is even less well known. Fewer sites are known with Middle Archaic components than for any other period, but the few surface collections available suggest the beginnings of regional cultural differences by the end of the period (Prikryl 1990). Diagnostic dart points that may be associated with the Middle Archaic include the Basal Notched group (which includes Calf Creek, Bell, and Andice), Wells, Dawson, Carrollton, and Bulverde (Prikryl 1990; Story 1990:Figure 31). An intact Middle Archaic component was identified at the Calvert site (41DN102) at Lake Ray Roberts (Ferring and Yates 1997). It is summarized as follows.

Hearths, a burial, an unmixed assemblage of artifacts and fauna provide new evidence of adaptations to a drier Middle Holocene landscape. Artifact types are similar to those from adjacent regions (Story 1990) suggesting broad cultural interactions. The foraging economy emphasized procurement of small game and deer. It is assumed that these people were quite mobile, as repeated occupations of the site during the [Middle Archaic] period are evident [Ferring and Yates 1997:305].

Population density may have reached a peak during the Late Archaic period in Northcentral Texas (ca. 1500 B.C.-A.D. 700). Evidence for this can be found in an apparent increase in the number of Late Archaic sites, a greater distribution of sites over the landscape, and evidence of decreasing group mobility (Prikryl 1990). At the same time, interregional contact may have diminished. If greater spatial dispersal of sites is not a result of sampling error due to unequal destruction or burial of earlier sites, it may reflect an economic system making increasing use of all available floral and faunal resources. Throughout Northcentral Texas, Late Archaic period occupation sites are relatively common in the uplands, and a relatively large number of buried sites are also known from the Trinity River flood plain (Ferring 1990:51). Dart points that may be diagnostic of the Late Archaic include Castroville, Marshall, Edgewood, Ellis, Trinity, Palmillas, Yarbrough, Dallas, Godley, Elam, and Gary (Prikryl 1990; Story 1990:Figure 31).

Investigations at Joe Pool Lake (Peter and McGregor 1988) and Lake Ray Roberts (Ferring and Yates 1997) indicate that remains of the Late Archaic period are characterized by assemblages apparently left by small bands of foraging hunters and gatherers who occupied a locality for a limited time period and then moved to another locality. These sites were apparently reoccupied numerous times on a seasonal basis. Faunal remains indicate that Late Archaic populations exploited a mix of prairie, forest, and riparian species, with white-tailed deer, rabbits, turtles, and mussels being primary food resources (Ferring and Yates 1997:6). In summarizing the results of investigations at a number of Late Archaic sites at Lake Ray Roberts, Ferring and Yates (1997:305) state: 
The most substantial occupations of the project area took place in the later part (post-3,000 yr bp) of the [Late Archaic] period. This is clearly a broad regional trend . . . although poor site exposure limits our understanding of earlier periods. Late Archaic sites here uniformly register mobile foragers that exploited all habitats available to them. Residential mobility . . . is implied. Repeated occupations at multiple sites were characterized by use of rock-lined and unlined hearths. On stable surfaces these are recorded as rock middens. In aggrading environments, discrete hearth construction events are clear. Import and curation of chert tools is evident, and contrasts with core-biface curation in the [Middle Archaic] period. Chert was preferentially used for straight, expanding and cornernotched points, while local raw materials were reduced on-site and dominate the contracting-stemmed forms. Despite quite good resource availability, dietary stress is recorded from skeletal and dental analyses. ... .

The documentation of large pits associated with Late Archaic period sites in the Richland Creek and Chambers Creek drainages (Bruseth and Martin 1987) also suggests that important sociopolitical changes may have been occurring during this time period. Unfortunately, the significance of these pits remains an enigma despite their excellent documentation.

\section{Late Prehistoric Period}

The beginning of what is called the Late Prehistoric period in the upper Trinity River basin (ca. A.D. 700-1700) is marked by the initial appearance of arrow points. The A.D. 700 date for the start of this period is based upon dated contexts for similar material in the Brazos River drainage to the west. Both Lynott (1977) and Prikryl (1990) have proposed that the Late Prehistoric period be divided into an early and a late phase, with the early phase reflecting a continuation of the foraging subsistence system of the preceding Late Archaic period and the late phase reflecting Southern Plains influences. In this view, the early phase dates between A.D. 700 and 1200 and is characterized by sand- and grog-tempered ceramics and Scallorn, Steiner, Catahoula, and Alba arrow points (Lynott 1977; Prikryl 1990). The late phase dates from A.D. 1200 to 1700. It is associated with the appearance of shell-tempered Nocona Plain ceramics, various unstemmed triangular points (e.g., Maud, Fresno, Harrell, and Washita), and Perdiz points (Lynott 1977; Prikryl 1990). Evidence of horticulture and bison procurement also appears in sites of this period (Harris and Harris 1970; Morris and Morris 1970).

As a result of intensive excavations at the Cobb-Pool site (41DL148) at Joe Pool Lake, Peter and McGregor (1988) proposed a reformulation of the Late Prehistoric period. The Cobb-Pool site yielded house structures, roasting pits, Alba points, grog-tempered ceramics, and charred corn cupules. Radiocarbon dates from several features indicate the site was occupied during the late twelfth or early thirteenth century. Present evidence suggests that the site does not represent an intrusive Caddoan occupation; consequently, a significant adaptive change appears to have occurred, in at least some areas, during a middle phase of the Late Prehistoric period. It is also likely that ceramics were not introduced to the region before this time.

In regard to the Late Prehistoric components investigated at Lake Ray Roberts, Ferring and Yates (1997:305) summarized the results of that research as follows:

There are no woodland-like sites in north-central Texas, suggesting that Plains Woodland influence/contact did not characterize the transition to the Late Prehistoric period. No ceramics were found with [Late Prehistoric I] assemblages, which have Scallorn, Alba and small Gary points. These 
appear to be short-term occupations that took place under conditions of reduced precipitation compared to the Late Archaic. Except for the replacement of darts with bow-arrow weaponry, these occupations are essentially similar to the Late Archaic. Regional exchange of technological information, rather than environmental change, probably is the factor behind the [Late Archaic] to [Late Prehistoric] shift.

Late Prehistoric II occupations are characterized by multiple, short-term use of probably logistic sites which lack ceramics and architecture. The architectural remains at 41DN102 are the only ones in the project area. At best, this was a small hamlet, occupied ca. 500-650 yr. bp. No evidence of horticulture was recovered, and the [Late Prehistoric II] faunas indicate a foraging strategy that emphasized deer procurement and occasionally bison as well. Transport and curation of chert raw materials was about as frequent as in the [Late Archaic], and long-distance raw material acquisition (e.g., Edwards, Alibates) is not evidenced. Ceramic traditions are dominated by locally produced shell-tempered wares, which by this time were being produced in the Southern Plains region generally. As recorded by previous synthesis (Story 1990) little if any interaction with the Caddoan area is indicated. Thus, the Ray Roberts prehistoric data suggest that regional traditions emerged at the end of the [Late Prehistoric] period largely independent of the Plains or East Texas Woodlands.

More recently, McGregor (personal communication 1999) has argued strongly for a "middle subperiod" of the Late Prehistoric, that he dates between A.D. 1000 and 1350 . He believes that arrow points with straight or rectangular stems are most diagnostic of this period and identifies three sites or site areas with relatively clean (or minimally mixed) components of this middle subperiod-the Cobb-Pool site, Area B at the McDonald site (41HI105) on Hackberry Creek in the middle Brazos River drainage, and Area F at the Haley's Point site (34MA15) on the Red River (Brown et al. 1987; Peter and McGregor 1988; Rohn 1998). McGregor also notes that maize is common at Haley's Point, as it is at Cobb-Pool, and suggests that these sites are representative of a relatively short-lived, region-wide subsistence pattern involving a partial dependence on agriculture during this middle subperiod (McGregor, personal communication 1999).

While no one can dispute the presence of domesticates at Cobb-Pool and Haley's Point, the lack of any evidence for Late Prehistoric agriculture at Ray Roberts Lake and Lewisville Lake leaves open the question of how extensive and how early this agricultural pattern was. Maize agriculture is known to have been present at Late Prehistoric sites along the East Fork, based on the recovery of maize from the Hogge Bridge, Butler Hole, and Campbell's Hole sites earlier during this century (Stephenson 1952:305), but the dating of these remains has always been uncertain (Prikryl 1990:77). As late as 1993, the available data allowed Fritz (1993:241) to state that, apart from Cobb-Pool, Late Prehistoric sites in Northcentral Texas seemed to show a generalized adaptation in which the most important plant foods were nuts, wild seeds, fruits, and the problematic, possible tuber that might be a species of Psoralea. Since then, several small projects have shed additional light on the introduction of maize horticulture into Northcentral Texas. The Harbor Pointe site (41DL369), located on Rowlett Creek (a tributary of the East Fork of the Trinity River) yielded remains of at least four individuals dated by AMS analysis of bone collagen to cal A.D. 1010 (1035) 1165. No pottery was recovered with these remains, although shell beads and a shell gorget were present, and a stable carbon isotope ratio of -21.6\%o indicates that the group's diet contained little or no maize (Cliff et al. 1996; cf. Lynott et al. 1986:Figure 2). More recently, a disturbed burial (41DL373), located on Spring Creek (a tributary of Rowlett Creek), was dated by AMS analysis of bone collagen to cal. A.D. 1155 (1220) 1275, with a stable carbon isotope ratio of $-17.8 \%$ o (Peter and Clow 1999). This value is similar to stable carbon isotope values believed to represent the initial introduction of maize agriculture in New York 
around A.D. 1000 (van der Merwe and Vogel 1977) and is comparable to values of $-18.0 \%$ to -20.0\% for initial maize-consuming Caddo populations in Arkansas (Rose and Hoffman 1989). Assuming that (1) these carbon isotope ratios directly reflect changes in the $\mathrm{C}_{4}$ plant contribution to the human diet (see Herz 1990 for a discussion of other possibilities), and (2) these burials are representative of more regional changes in prehistoric dietary patterns, then maize horticulture may have been introduced into Northcentral Texas around A.D. 1200.

\section{Historic Indian Period}

Within Northcentral Texas, the time from A.D. 1700 to 1850 has been designated the Historic Indian period (Prikryl 1993). Prior to the founding of New Mexico in 1598, the European presence in the Southwest and on the Southern Plains was sporadic at best (Coronado in 15401541, the Rodriguez-Chamuscado party in 1581, Espejo in 1582-1583, etc.). After 1598, Spanish influence was never absent from the Southern Plains although actual contact with Europeans continued to be limited and there are only brief records of journeys into or through the area (Hofman 1989b; John 1975). Despite this, it was not until the beginning of the nineteenth century that the physical presence of Europeans on the Southern Plains became commonplace. This was the result of increasingly peaceful relations between the Spanish in Texas and the Plains Indians to the north, and the acquisition of Louisiana by the United States in 1803. Prior to about 17251750, Apachean groups appear to have dominated the western portion of the Southern Plains, known as the High Plains. After this time, the area was increasingly controlled by the Comanche and Kiowa. On the eastern portion of the Southern Plains, within the area now known as the Lower Plains and Northcentral Texas, the Wichita tribes became dominant (Bell et al. 1967; Hofman 1989b:91).

Unfortunately, since good historical documentation is very sparse for the upper Trinity River basin during the early historic period, it is not clear which specific aboriginal groups were residing in the Dallas area at the beginning of this period. What is clear is that the early historic period in Northcentral Texas was a time of population fluctuation, movement, and amalgamation (see Newcomb 1993). Available data suggest that many, if not all, of the aboriginal occupants of the eastern margin of the Great Plains, including Northcentral Texas, were Caddoan language speakers, from the Arikara in the north to the Wichita and Kichai in the south. In this light, it is worth noting that it has also been suggested that the Socoatino, encountered by the survivors of the de Soto expedition in the sixteenth century, were Caddoan speakers and were the same as the Canohatino, identified by the French in the latter part of the seventeenth century, apparently located at that time "on the Blackland Prairies between the Guadalupe and Trinity rivers to the east of present-day San Antonio, Austin, and Waco” (Newcomb 1993:24). If the prehistoric occupants of the eastern margin of the plains in Texas were indeed Caddoan speakers, it would explain how they were absorbed very early by other Caddoan-speaking groups (such as the Yojuane, Kichai, Tawakoni, Taovayas, Iscani, and Wichita proper) who arrived in Northcentral Texas in the late seventeenth and early eighteenth centuries. Most of these groups, in turn, amalgamated to form the historic Wichita Tribe. However, some were probably absorbed by the united Caddo Tribes, and some may even have joined amalgamations of a variety of groups, such as the Tonkawa, during the late eighteenth and early nineteenth centuries. 
The term Wichita is commonly used to refer to a group of linguistically related tribes, including the Wichita, Taovayas, Tawakoni, Iscani, Waco, and Kichai. Many of these groups apparently entered the Southern Plains in the seventeenth century, probably from Kansas and southern Nebraska, to escape the hostilities of the Osage (Webb and Carroll 1952:2:904). The Wichita were true Plains Villagers, with an economy that was jointly dependent upon agriculture and bison hunting. They occupied permanent villages of beehive-shaped, grass houses, from which they conducted seminomadic bison hunts. In 1719 their villages were located along the Arkansas River in northern Oklahoma (Hofman 1989b:95). By 1750, they had moved some of their villages to southern Oklahoma, along the Red River. Others were located on the upper end of the Sabine and Neches rivers in Texas and subsequently on the middle Trinity and upper Brazos rivers. In 1772, the year they concluded a nominal peace with the Spanish, one of their villages was on the Salt Fork of the Brazos, on the Lower Plains west of Dallas (John 1975:Map 3; Webb and Carroll 1952:2:705). Wichita groups were included in treaties made with the Republic of Texas in 1843 and with the United States in 1837 and 1856 (Webb and Carroll 1952:2:709). In Texas, they continued to live between the upper Brazos and Trinity rivers until 1855. In that year, the Tawakoni and Waco were placed on the Brazos Indian Reservation, south of Fort Belknap, in company with a number of other Native American remnant groups (Smith 1996; Webb and Carroll 1952:1:212; 2:905). Subsequently, as a result of increasing animosity from white settlers, they were removed to Indian Territory in 1859 (Smith 1996; Webb and Carroll 1952:1:210). The remnants of the Wichita moved to Kansas during the Civil War, but returned to Oklahoma after the war to settle permanently near present-day Anadarko (Hofman 1989b:95).

Archeological remains that can be associated with these early historic groups are rare compared to the remains of earlier periods. Within the upper Trinity River basin, and in Dallas County itself, little evidence of these historic Indian groups has been found, with the exception of a few Native American sites with European items (Sollberger 1953).

\section{Historic Occupation/Utilization}

The first presence of Europeans in Northcentral Texas may have been in 1542, when the remnants of the de Soto expedition, led by Luis de Moscoso de Alvarado, entered modern Texas in an effort to find a land route to New Spain. Some researchers believe that the expedition crossed Northcentral Texas (Lebo and Brown 1990:61), although others place the route much farther to the east and south (Bruseth and Kenmotsu 1991; Chipman 1992; Hudson 1986; Schambach 1989; Weber 1992). A consistent European presence in the region did not occur until the early 1700s, when French traders from Louisiana began to move west along the Red River. The Spanish considered this French incursion to be a threat to the security of New Spain, and they responded by redoubling efforts to counterbalance the French influence with the Native Americans in East and Northcentral Texas. These efforts continued until 1763, when France ceded Louisiana to Spain under the Treaty of Paris. This reduced the perceived threat to the security of New Spain and resulted in a reduction in Spanish investment in eastern and northern Texas. More important, from the Native American viewpoint, was the severe military defeat inflicted on the Spanish by Wichita and allied tribes at Spanish Fort on the Red River in 1758. It has been argued that this defeat put an end to Spanish military and missionary expansion to the north (Weddle 1964, 1965). 
The first Euro-Americans to settle in the region were primarily from Arkansas Territory. The settlement of Bird's Fort, established in 1840, was the first permanent settlement in the DallasFort Worth area, and was established by Captain Jonathan Bird. Located along the West Fork of the Trinity River in present-day Arlington, the fort consisted of a blockhouse and several log buildings, and served mostly as a trading station. Additional families joined the initial occupants of the fort in the fall of 1841, but the fort was abandoned by the spring of 1842. Bird's Fort was not used again until the summer of 1843 when Sam Houston, President of the Republic of Texas, attempted to meet with the Indian tribes and establish a peace treaty. The treaty was signed on September 29, 1843, with representatives of the Delaware, Chickasaw, Waco, Keechi, Caddo, Ionic, Biloxi, and Cherokee present (Garrett 1972; Sergeant 1953).

Meanwhile, in 1841, the Republic of Texas had granted a large portion of land to the Texas Emigration and Land Company (TELC), which hoped to encourage settlement of Northcentral Texas. The grants distributed to settlers by the TELC became known collectively as the Peters Colony. The majority of the Peters Colony settlers held property north of Dallas, which they held in that name until 1852 when disputes between the TELC and the settlers caused some of the settlers to band together to defend their title to the land they had settled.

In 1845, a trading post was established at Marrow Bone Springs (later named Mary Le Bone Springs) along Johnson Creek (formerly called Mill Creek). Although Carol Werdman's (1969:10) account of its location suggests either a Rush Creek or Johnson Creek location, an 1872 map of Texas (Petermann 1872) places Marrow Bone Springs on Johnson Creek. Colonel Middleton Tate Johnson and a company of Texas Rangers also established their headquarters at Marrow Bone Springs in 1847. Two years later Colonel Johnson received a land grant for his services, and he established a plantation near Marrow Bone Springs. The community that grew around the colonel's plantation came to be known as Johnson Station. Shortly after the establishment of Johnson Station, Camp Worth was established in 1849 at the junction of the Clear and West forks of the Trinity River in order to provide protection for settlers along the western frontier. In the same year, Colonel Johnson was instrumental in the political process of establishing Tarrant County.

Tarrant County was seriously affected by the Civil War, which reduced the population of nearby Fort Worth from 6,000 inhabitants to just 1,000. However, the blossoming cattle industry motivated population and economic growth in the area through the end of the nineteenth century, with hundreds of thousands of cattle driven through the region. The arrival of the Texas \& Pacific railway brought increased economic growth and modernization to Tarrant County; water and sewer systems and paved roads were introduced in the 1880s and 1890s. The discovery of oil near Ranger, Texas, in 1917 contributed to a great economic boom during World War I and World War II (Skinner et al. 1997).

The settlement of Birdville, located between Little Fossil Creek and Big Fossil Creek (Figure 3a), was founded soon after Bird's Fort was abandoned 12 miles to the southeast. The community of approximately 50 farmers and ranchers was founded in 1848 and was quickly followed by Fort Worth in 1849. The same year, Tarrant County was formed, and the role of county seat was sought by both Birdville and Fort Worth. In the 1850 election, Birdville won the seat, and promptly built a courthouse. In 1856, a special election was held to re-determine the county seat; this time, Fort Worth won by a few votes. Fort Worth citizens retrieved the county courthouse furniture and records. At the cost of at least $\$ 30,000$ and several lives, the election results were 
Predictive Model for Archeological and Historic Site Locations: Big Fossil Creek Drainage, Tarrant County, Texas

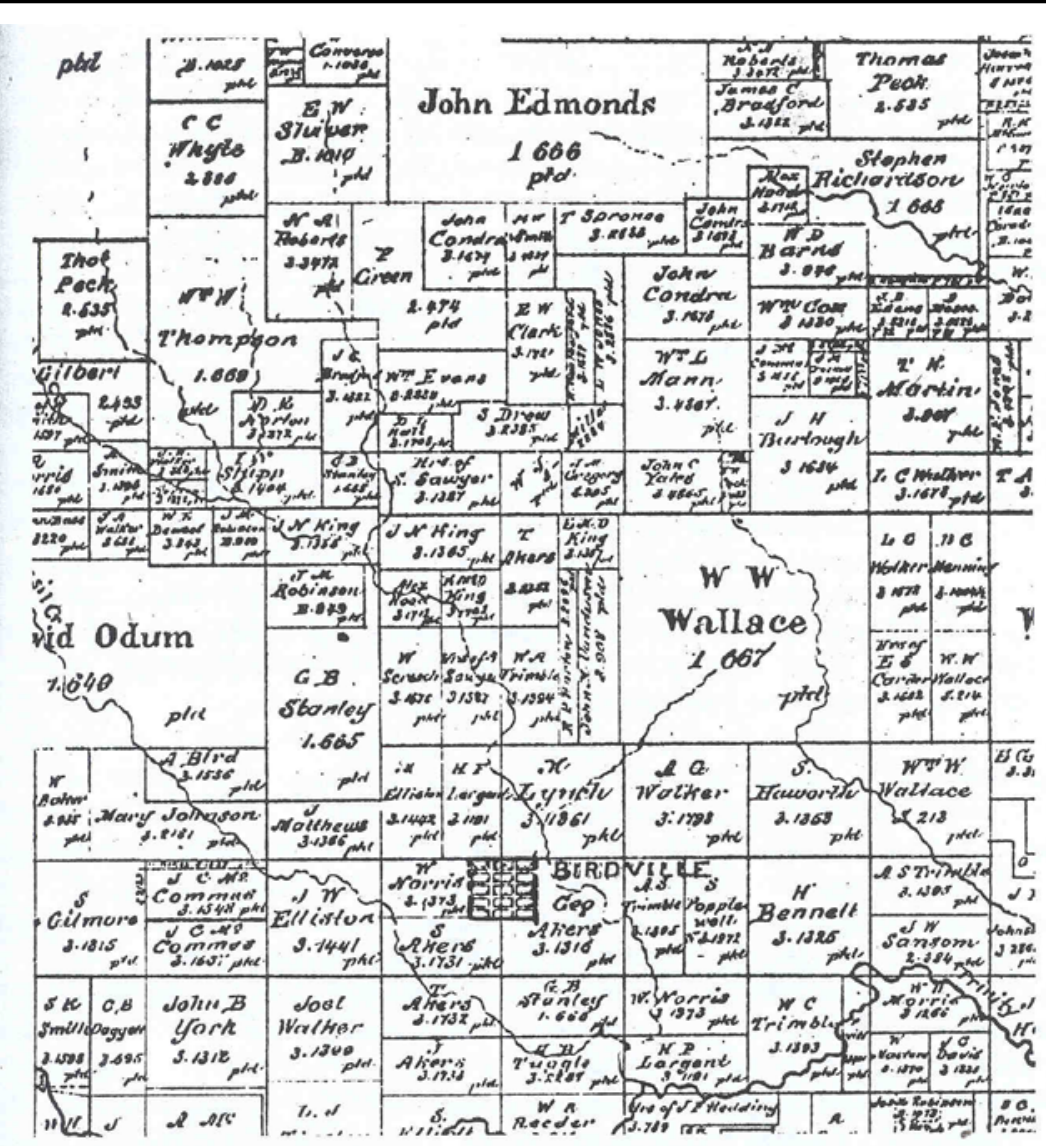

a.

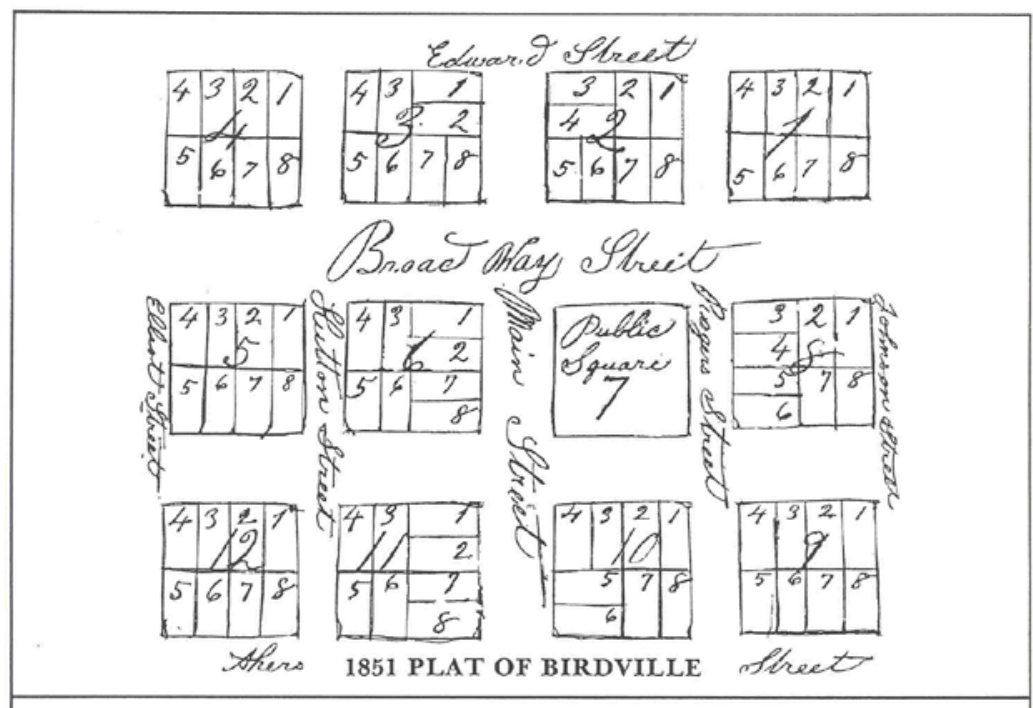

b.

Figure 3. Maps of Birdville: (a) location on the 1855 Tarrant County Land Grant Office map; and (b) 1851 Plat Map. 
contested for years. A final election in 1860 soundly defeated Birdville. Thus, Birdville grew slowly until the mid-twentieth-century. The population remained under 100 through the 1930s. Incorporation of nearby communities in the 1950s and 1960s increased the population to over 20,000. Haltom Village, a small community founded in 1932 on the outskirts of Birdville, also grew steadily, eventually incorporating Birdville in the 1950s and becoming present-day Haltom City (City of Haltom City 1997). 
Predictive Model for Archeological and Historic Site Locations: Big Fossil Creek Drainage, Tarrant County, Texas 


\section{CHAPTER 3 SITE POTENTIAL WITHIN FOSSIL CREEK DRAINAGE}

\section{PREVIOUS ARCHEOLOGICAL INVESTIGATIONS}

Many of the archeological investigations undertaken in Tarrant County have been associated with reservoir projects. Lake Benbrook was surveyed by the River Basin Survey in 1948, but no sites were discovered (Stephenson 1949). Survey, testing, and mitigation efforts were undertaken in the 1970s and 1980s at Joe Pool Lake (Lakeview Reservoir) (Ferring and Reese 1980; Jurney et al. 1988; Peter and McGregor 1988; Raab and Woosley 1982; Raab et al. 1982; Skinner and Connors 1979). The Texas Water Development Board has sponsored several investigations in the county (Jurgens 1982; Whitsett 1976; Whitsett and Fox 1979, 1980). Considerable work has been done in the region by both the Dallas and Tarrant County Archeological societies, with excavations by the Tarrant County Archeological Society at site 41TR56 being reported by Johnson (1956).

Several major reports concerning the archeology of the upper Trinity River basin (Peter and McGregor 1988; Prikryl 1987, 1990; Yates and Ferring 1986) summarize the history of archeological investigations within the upper Trinity River drainage and the cultural-historical framework for the area. Although the combined efforts of professional and avocational archeologists have recorded numerous sites, much research remains to be done. As noted by McGregor (1988:27-29), much of the excavation efforts within the upper Trinity River basin have focused on reservoir development, especially along the Elm Fork (Crook and Harris 1957, 1958, 1961; Skinner and Baird 1985; Skinner et al. 1982) and the East Fork (Dawson and Sullivan 1973; Lorrain and Hoffrichter 1968; Lynott 1975; Ross 1966). Field school excavations by the University of Texas at Arlington at the Northlake site on Grapevine Creek were also reported in the mid-1970s (Morgan 1975). Investigations at Joe Pool Lake (Jurney et al. 1988; Peter and McGregor 1988) have provided the initial assemblage data necessary for an understanding of cultural adaptations along the West Fork. Work at the River Bend site, 41TR68 (Peter et al. 1987), which lies less than a mile south of the current project boundary, has also contributed to preliminary interpretations of regional prehistory.

Several archeological studies in the Upper Trinity River Basin have occurred east of the current project area in Arlington, Grand Prairie, and southwest Dallas. These studies suggest that prehistoric archeological sites are relatively common along the West Fork of the Trinity (Burson 
and Cliff 1999; Burson et al. 1999; Ferring 1994; Ferring and Byers 1996; Peter and Gaither 1990; Shaunessy et al. 1994; Trask et al. 1995). In general these sites are both well preserved and deeply buried within flood plain deposits. Despite their density, they tend to be rarely documented and poorly understood, in part because deposits consist primarily of bone, shell, and hearth features as opposed to obvious lithics or other artifacts.

GMI has conducted a number of projects within the city of Fort Worth, including locations at the Fort Worth Zoo (Edwards and Peter 1991), the Tarrant County Railtran corridor (Hunt et al. 1993), and the East First Street Bridge, which revealed a National Register-eligible prehistoric site, 41TR138, which lies just outside of the current study area (Largent et al. 1994). A 1996 survey for the proposed Villages of Fossil Creek, which falls within the current project area, revealed no cultural resources (Krapf and Hunt 1996).

Twelve cultural resources surveys have been conducted in the Big Fossil Creek watershed project since 1976 (Texas Historical Commission [THC]). However, according to the Texas Archeological Research Laboratory (TARL) in Austin, only four sites have been recorded within the project area (41TR121, 41TR122, 41TR131 and 41TR132), and three more (41TR68, 41TR72, and 41TR138) have been located within one mile of the project boundary (Figure 4). No structures within the project boundary have been included on the National Register and no State Archeological Landmarks exist within the project area. No site forms were ever recorded for sites 41TR121 and 41TR122; therefore, no information concerning the cultural affiliation of these sites is available. Sites 41TR131 and 41TR72 are historic trash scatters, and sites 41TR132, 41TR68, and 41TR138 are described as prehistoric shell accumulations with flakes and/or hearths present. The historic sites are located on the first terrace above a creek. The prehistoric sites, identified in cut banks, are both situated within flood plains.

Two of the sites located within the project area (site 41TR131 and 41TR132) were recorded during a 100-acre survey of a portion of Whites Creek conducted by AR Consultants in 1993 (Skinner and Whorton 1993). The survey was carried out in this area via limited subsurface shovel testing and visual inspection of the eroded creek bank and surrounding surface. Site 41TR131 is a historic trash scatter, likely associated with a residence shown on the 1924 soils map of the area. Artifacts include bottle glass, brick, earthenware, plastic, and cans dating from the 1930s to approximately the 1960s. The trash is accumulated on a small "bench" and spills down the eroded slope of the bench almost to the creek, covering an area approximately $15 \mathrm{x}$ 20 m (Skinner and Whorton 1993).

Site 41TR132 is a prehistoric shell lens exposed in the creek bank near the junction of the two arms of Whites Creek. The site is approximately $1 \mathrm{~m}$ below the current ground surface and extends 3-4 $\mathrm{m}$ along the bank. The site consists of a 10-cm thick layer of fire-reddened limestone slabs associated with freshwater mussel shells. No bone, lithic debitage, or chipped stone tools were found in association with the shell lens. This site is interpreted as a mussel-collecting locality (Skinner and Whorton 1993).

Skinner and Whorton (1993:21) conclude from their historic research of the Whites Creek area that the Chisolm Trail may have run close to their project area. In particular, they cite the 1870s General Land Office map that shows a north-south trail passing east of Whites Creek. The trail is unnamed on the map and Skinner and Whorton (1993:16) note "Creeks to the east and west are 
figure

4. Previously surveyed areas and location of historic Birdville settlement 
Predictive Model for Archeological and Historic Site Locations: Big Fossil Creek Drainage, Tarrant County, Texas

\section{figure 4}


mapped wrong." If the Chisolm Trail passed through the project area, the wagons and cattle following the trail would have left a mark in the landscape in the form of wagon swales. These swales could still be visible today in relatively undeveloped areas in the region.

As noted above, no information is available on the remaining two sites (41TR121 and 41TR122) located within the current project area.

Sites located within one mile of the project boundary are similar in nature to those recorded at Whites Creek. Site 41TR68, the River Bend Site, located just south of the project boundary along the West Fork of the Trinity River, is visible in the cut bank (TARL site data form; Peter et al. 1987). The site is described as a riverside campsite/mussel-collecting area measuring approximately $150 \times 30 \mathrm{~m}$, but is thought to have been larger during its occupation. Artifacts recorded include shell, burned rock, and lithic material and were recorded 0.75 to $1.5 \mathrm{~m}$ below the current ground surface. Excavations at this site have helped to lay the foundation for understanding adaptations along the Trinity River.

Site 41TR138 is another mussel-collecting site located west of 41TR68 on the east bank of the West Fork measuring approximately 300 x 50 m (TARL site data form; Largent et al. 1994). The site was exposed through backhoe trenching and hand-excavated units. Artifacts identified include two flakes, bone, and turtle shell. Features observed include three hearths exposed in the backhoe trenches and a thick shell lens located $1.7 \mathrm{~m}$ below the current ground surface. The hearths are described as basin-shaped lenses of fire-cracked rock. Concentrations of charcoal were also found in association with these deposits and the site has been recommended for inclusion in the National Register of Historic Places (Largent et al. 1994).

Site 41TR72 is located off the eastern edge of the project boundary just west of the Saginaw airport along Willow Creek (TARL site data form). This site is described as a $15-\mathrm{x}-15-\mathrm{m}$ scatter of historic material dating from approximately 1890 through 1950 and is located on the edge of the first low terrace formed by the creek. The site is too small to represent the location of a house or other structure, but rather, is likely trash associated with an occupation.

The dearth of sites previously identified within the project area may be a function of the small percentage of the property that has been systematically surveyed for cultural resources, and the rapid urban expansion of private development. A search of THC records produced few of the reports from the 12 surveys conducted in the drainage. Two reports found at the THC covered small surveys for alternative locations of a wastewater interceptor (Fox 1979; McCormick 1976). Both surveys were conducted in the southernmost portion of the current project area, near the confluence of Little Fossil and Big Fossil creeks. While neither survey recovered cultural material, both authors concede prehistoric remains may be deeply buried in the flood plain deposits. However, both assert these remains would be widely scattered and sparse, and discovery of such remains via survey would be unlikely.

Surveys conducted more recently by AR Consultants (Skinner 1997; Skinner and Whorton 1993; Trask and Whorton 1995; Whorton and Skinner 1995) along Whites Creek and at the confluence of Whites and Big Fossil creeks, also indicate that while the potential for prehistoric remains exists, the likelihood of discovery is diminished by the depth of the flood plain deposits, the ephemeral nature of prehistoric use of the area, and modern development. 


\section{PREDICTIVE MODEL}

\section{Current Project Methodology}

Background research was conducted to locate previously reported sites in the Big Fossil Creek drainage and to determine which portions of the area had been surveyed for archeological resources. After the background research, a limited field survey was conducted to assess the current conditions of the area for site potential. Modern maps, including 7.5 minute U.S. Geological Survey (USGS) topographic maps (Haltom City, Hurst, Keller, Avondale, and Lake Worth quads), Mapsco ${ }^{\circledR} 2000$ Fort Worth street map, and aerial photography provided by the USACE, Fort Worth District, taken within the last three years, were consulted for a preliminary determination of developed and disturbed areas in the drainage. Historic maps, including Sam Street's Map of 1893, the Tarrant County Land Grant map of 1855, and the 1851 Plat map of Birdville were consulted for potential historic sites and architectural features.

Once the maps had been considered, field reconnaissance was conducted to identify areas of high probability for intact archeological deposits. Reconnaissance consisted of a general windshield survey of the area coupled with visual inspection of open areas and accessible creek cut banks. The windshield survey revealed that urban development mapped as a concentration in the eastern portion of the project area has spread — and continues to spread-at a rapid pace westward toward Interstate 35W, and north along Blue Mound Road west of I-35W.

Developed areas along Big Fossil Creek, Little Fossil Creek, and Whites Creek consist of housing developments, roads, and commercial property that run to the creek edges in many locations. Several golf courses have also been constructed on the flood plains. In some locations, a small buffer has been left between these developments and the creek edge. However, in most areas, fence lines and golf courses run right to the edge of the water (Figure 5). In many locations, the creek bed has been altered, through channelization, the construction of levees, and the installation of concrete erosion control systems for bridges. In all of the urbanized areas, the flood plain and/or first terrace above the creek are completely developed.

The windshield survey disclosed small tracts of undeveloped land within the urban core of the project area (Figure 6). Pedestrian reconnaissance of these areas revealed that even tracts not currently supporting modern development had suffered damage from gravel mining, erosion, and prior development, and that few maintain enough soil integrity and depth to potentially yield archeological deposits (Figures 7-9). The examined cut banks (Figure 10) showed greater stratigraphic integrity than other undeveloped tracts observed. However, while deeper components of the observed deposits contain fossilized and unfossilized mussel shell and limestone, no cultural material or significant concentrations of mussel shell were observed in the cut banks examined.

\section{Historic Resources}

The original town of Birdville has been lost to the modern-day growth of Haltom City. According to the 1851 plat map of Birdville, downtown Birdville was located in the blocks defined today by Broadway Avenue to the north, Rogers Street to the east, Walker Street to the 


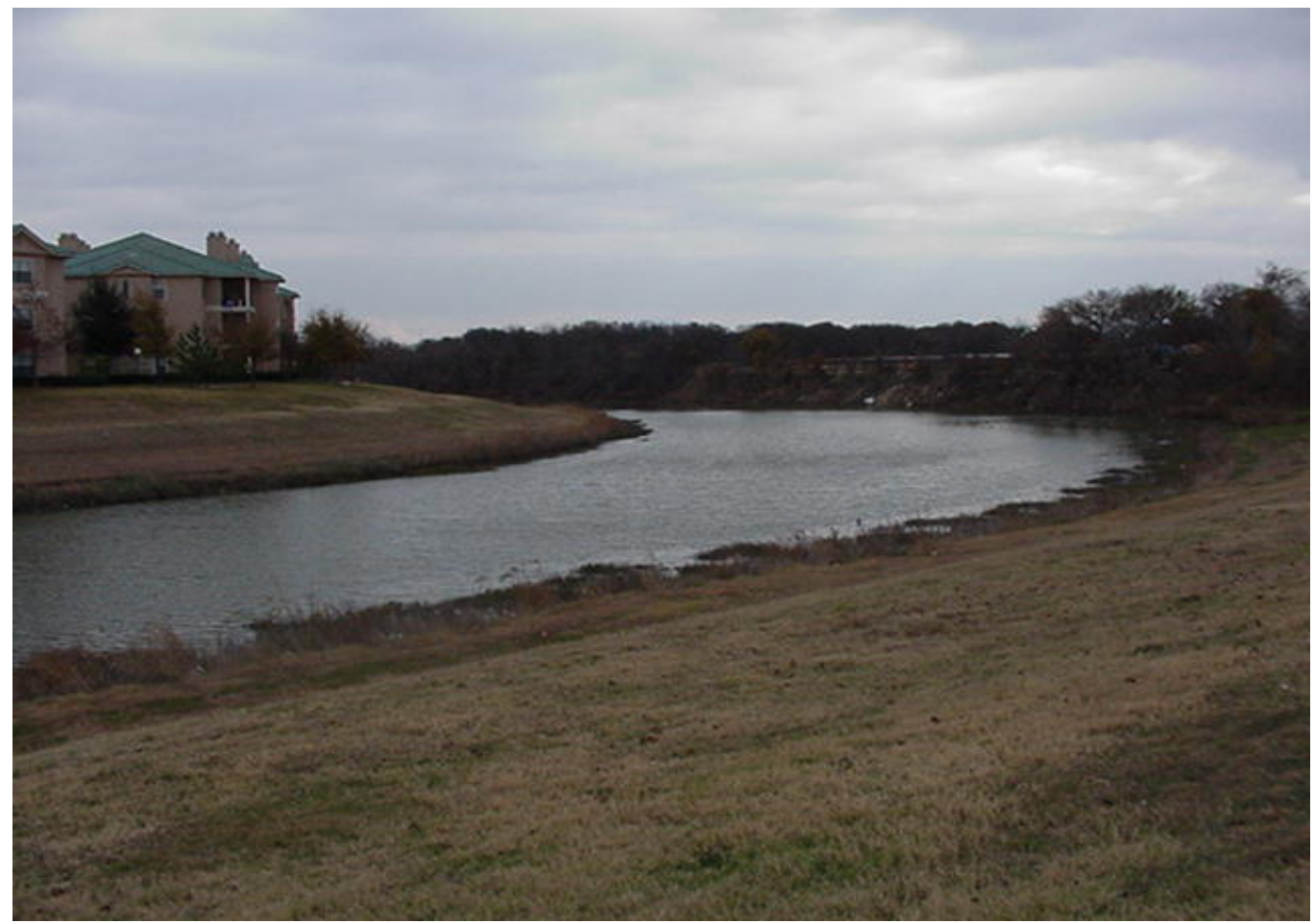

Figure 5. View of development along channelized bank of Big Fossil Creek.

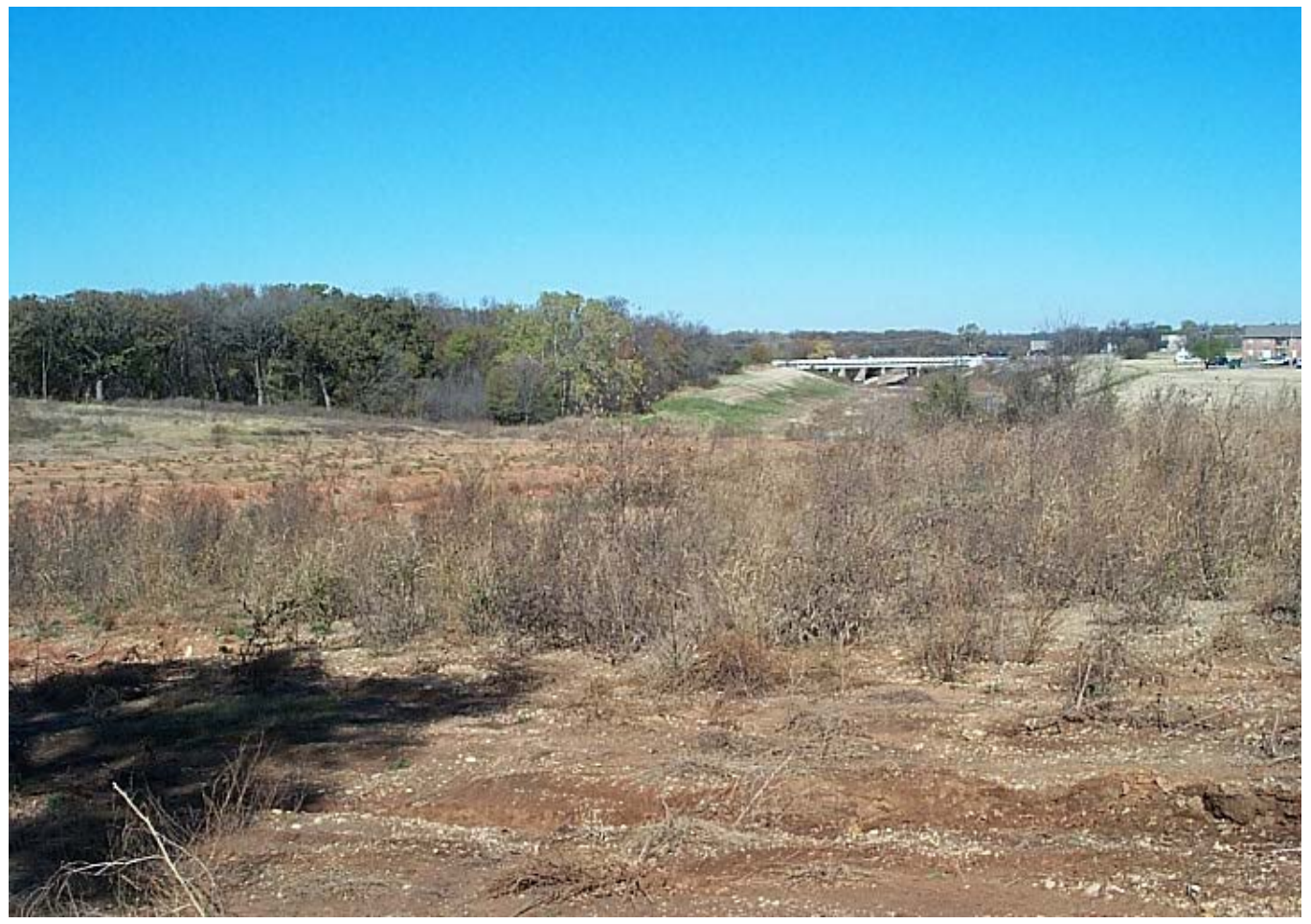

Figure 6. View of undeveloped tract along Big Fossil Creek showing erosion. 


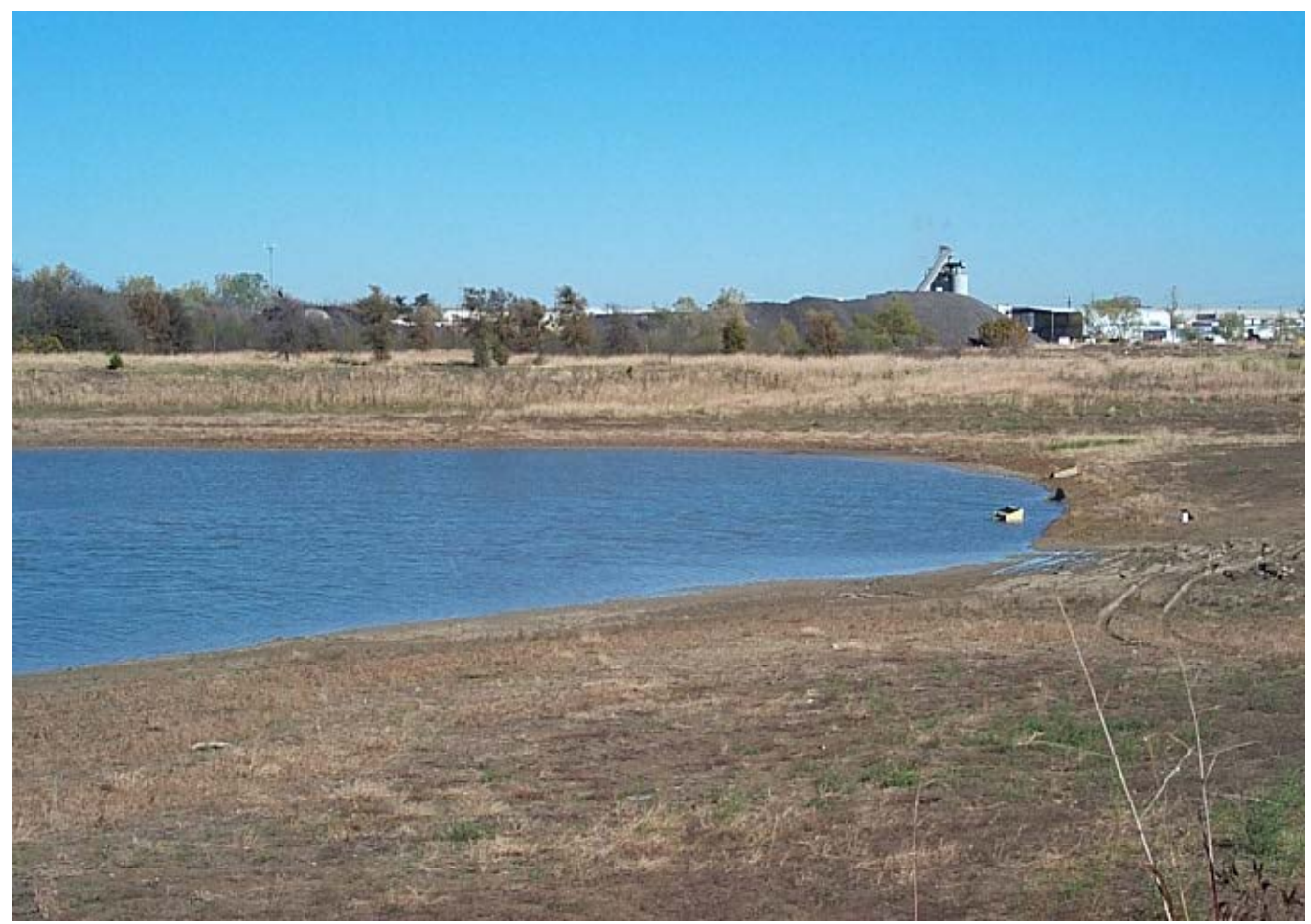

Figure 7. Borrow pit near the confluence of Big Fossil Creek and Trinity River with Austin Commercial gravel works in background.

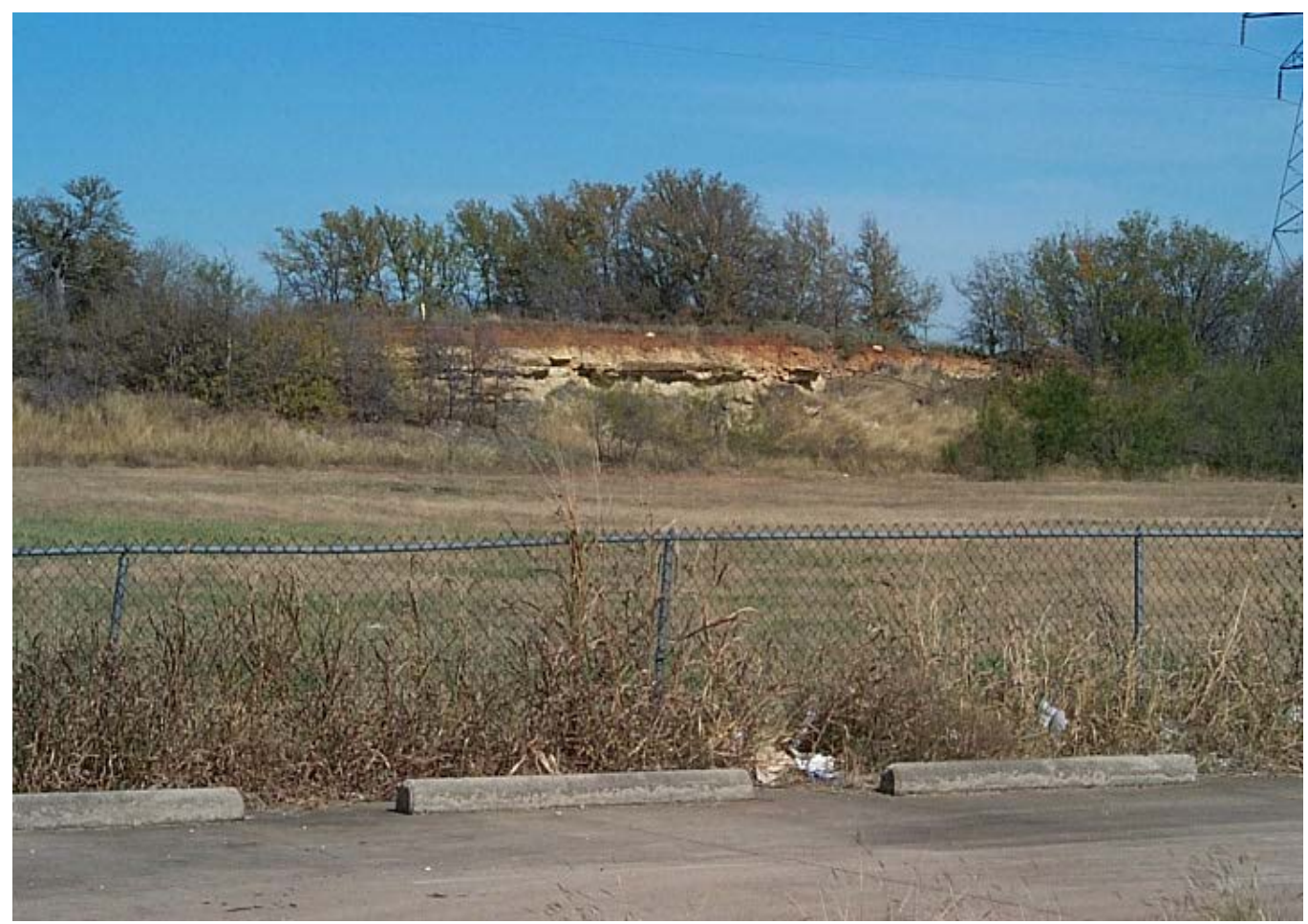

Figure 8. View of empty lot in abandoned gravel quarry; Big Fossil Creek drainage beyond tree line. 


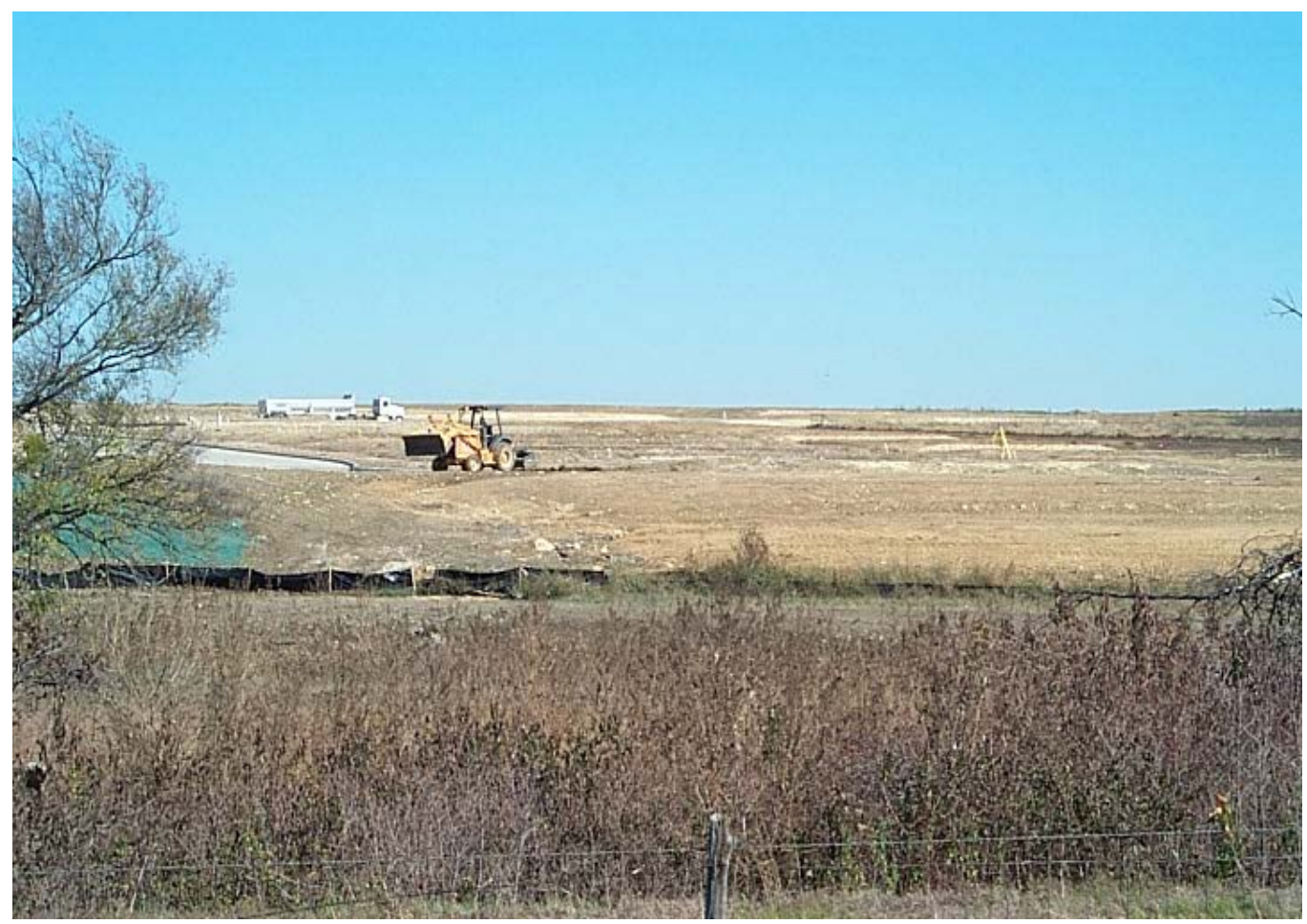

Figure 9. View of construction on the flood plain of Big Fossil Creek east of Blue Mound Road.

south, and Bewley Street to the west (see Figure 3b). The old Main Street has been renamed Carson Street. Today, the Birdville Baptist Church and its parking lot sit on the corner of Walker and Carson in the location of the old Birdville courthouse. The Shannon Education Center has been built across from the church on Carson Street, Birdville elementary school is a block south between Carson and Bewley streets, and the Birdville Coliseum is located east of the old Birdville public square on Broadway Avenue. No original structures from the center of Birdville are standing and most subsurface evidence of the original town buildings would have been destroyed when the church, schools, and coliseum were constructed. However, subsurface remnants of domestic buildings associated with Birdville may remain in the yards of lesser-developed residential areas within two or three blocks of the old square.

Birdville Cemetery is located approximately $1 / 4$ mile southeast of the corner of Carson Street and Broadway Avenue (Figure 11). Big Fossil Creek lies less than $\chi$ mile to the east of the cemetery, with no modern development between the two. Today, Birdville Cemetery is fenced and gated. It is not accessible to the public, but appears well maintained (Figure 12). An inventory of headstones published in The History of Birdville (Ray 1965) lists Margaret Potts, buried November 27, 1852, as the earliest marked grave. This list indicates interments continued until at least 1963. 


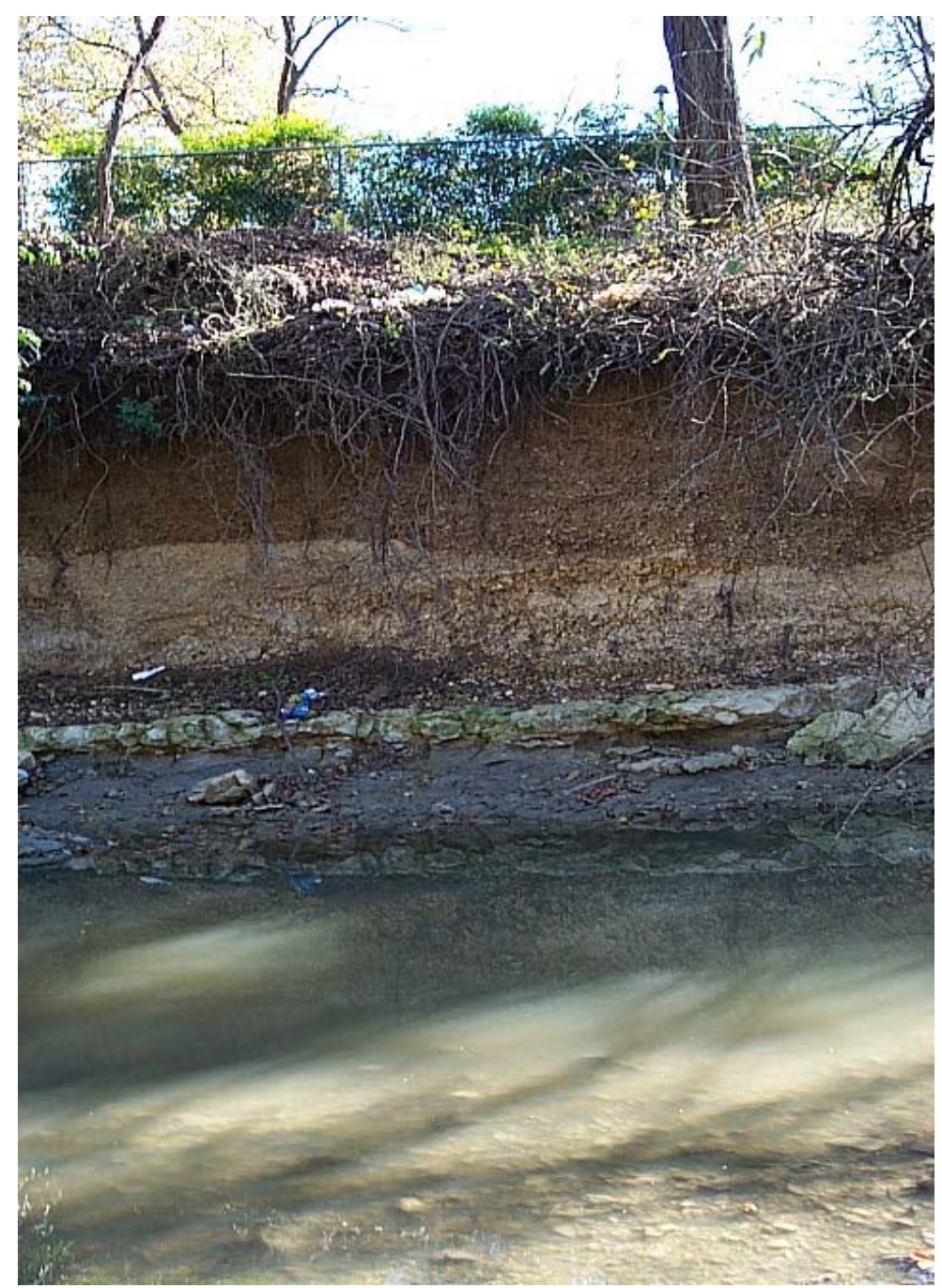

Figure 10. View of south cut bank, Little Fossil Creek.

\section{Site Potential/Recommendations for Future Work}

Prior to any work impacting the Big Fossil Creek drainage area, evaluation for archeological and architectural resources must be conducted. Archeological resources are locations and objects from past human activities, both prehistoric and historic. Architectural resources that must be considered are those standing structures that are usually over 50 years of age and are of significant historic or architectural importance to be considered for inclusion in the National Register. However, given the current conditions of the drainage area, modern development, and the expansive nature of the Grand Prairie in prehistoric times, future investigations into cultural resources in the area need not be extensive. 


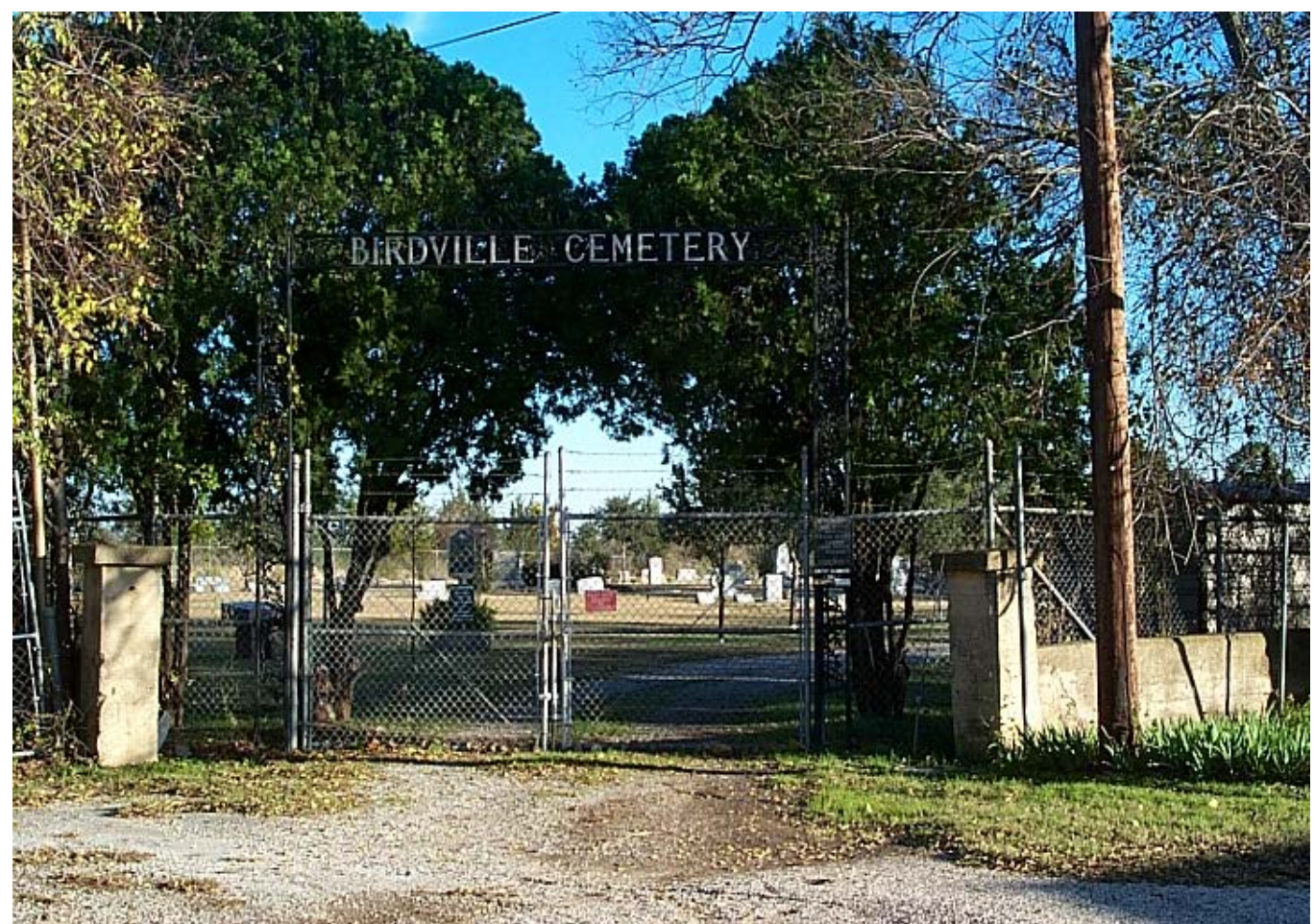

Figure 11. Front gate of Birdville Cemetery.

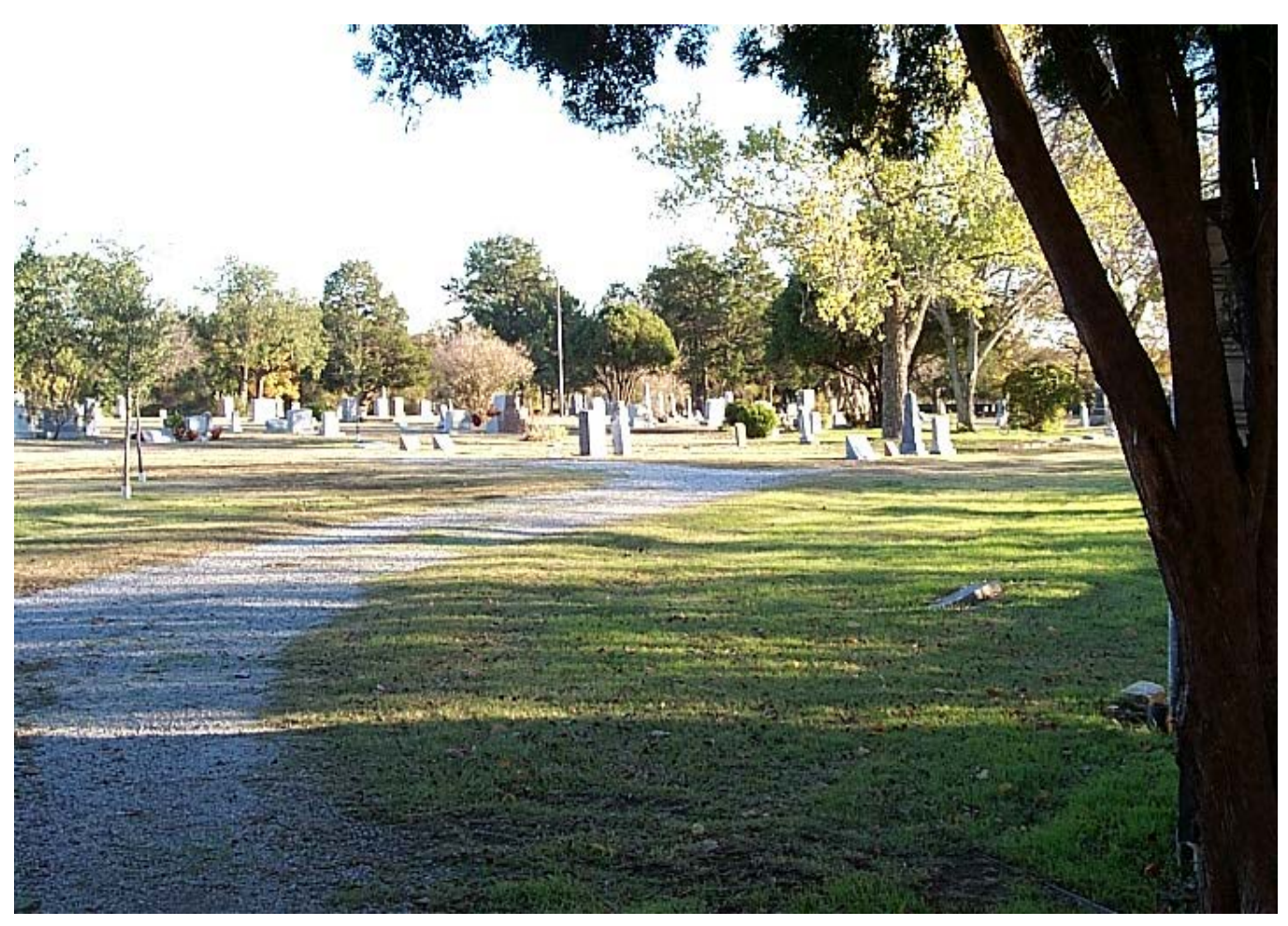

Figure 12. View of interior of Birdville Cemetery. 
In designing a predictive model for site probability in the watershed, several factors were taken into consideration as either 'attractors' or 'repellers' for site location. These factors include proximity to water, land forms associated with proximity to water such as flood plains and terraces, the locations of previously recorded sites, and data on potential historic features as shown on the 1893 Sam Street's map. In addition, factors such as urban development, creek bed channelization, mining activity, and erosion that may have disrupted site integrity were taken into consideration. These factors were developed into a GIS model for a graphic representation of areas with high and low potential for containing intact archeological remains (Figure 13). In developed areas, particularly older residential neighborhoods, an architectural survey should be conducted to evaluate standing structures for National Register eligibility prior to impact.

Areas of potential architectural significance within the project area were determined by consulting the Haltom City and Hurst USGS quadrangles. Residential areas that were shown to be in existence from aerial photographs taken during the 1950s were then compared to a set of 1996 digital orthophoto images that were produced by VARGIS of Herndon, Virginia, for the Texas Orthoimagery Program (TOP). By consulting the 1996 images it was possible to determine areas which could potentially contain remnants of older residential neighborhoods (Figure 14). These areas are limited in size and would likely be impacted only if proposed floodway construction were conducted some distance from the existing channel.

Modern urban development on the terrace above the creeks is rapidly growing, with apartment buildings, parks, golf courses, and houses built to the edge of the bank in many places, severely impacting and altering the landscape. Therefore, no survey is recommended for these impacted areas throughout the Big Fossil Creek drainage. The upland prairie, which includes the area west of Interstate 35, would have been only sparsely occupied in prehistoric times. The prairie provided little in terms of subsistence resources for hunter-gatherer groups beyond occasional herds of pronghorn or other large mammals. As such, the prairie was not densely occupied and remains of small short-term hunting camps would be very scarce and ephemeral. Because of the very low density of sites in a prairie setting and the intense modern development that has impacted the Big Fossil Creek drainage area, no archeological survey is recommended for the upland prairie portion of the drainage west of I-35.

On-site observation, research, and GIS modeling indicate that future archeological studies would be most productive if confined to the cut banks and edges along unaltered portions of the creeks throughout the eastern side of the project area. Cut banks examined at several locations along Big Fossil and Little Fossil creeks revealed stratified soil deposits; prior research indicates the best preserved prehistoric resources in the area are likely to be the remains of mussel gathering activities evident in such creek cut banks. These locations have the highest potential for undisturbed prehistoric deposits in the area, even where modern construction is most dense. In the southeastern portion of the drainage, the Eastern Cross Timbers would have been the dominant ecotone providing a greater variety of reliable foods for prehistoric populations. Site density would have been higher within the Cross Timbers than in the Grand Prairie, increasing in concentration closer to the West Fork of the Trinity River. The confluence of Big Fossil Creek and the West Fork would have been within the rich Trinity Floodplain Forest. In this area, cut banks should be intensively surveyed for archeological deposits. In the flood plain regions adjacent to the creeks and river, backhoe trenching is recommended to locate potentially deeply buried deposits. 
figure

13. Map showing the potential for intact prehistoric cultural resources 
Predictive Model for Archeological and Historic Site Locations: Big Fossil Creek Drainage, Tarrant County, Texas

\section{figure 13}


figure

14. Areas of potential architectural significance within project area 
Predictive Model for Archeological and Historic Site Locations: Big Fossil Creek Drainage, Tarrant County, Texas 


\section{REFERENCES CITED}

Barnes, V. E. (Project Director)

1988 Geologic Atlas of Texas, Dallas Sheet. Bureau of Economic Geology, University of Texas, Austin.

Bell, R. E., E. B. Jelks, and W. W. Newcomb (assemblers)

1967 A Pilot Study of Wichita Indian Archaeology and Ethnohistory. Submitted to the National Science Foundation.

Blair, W. F.

1950 The Biotic Provinces of Texas. Texas Journal of Science 2:93-117.

Brown, D. O., R. P. Watson, D. Peter, and R. Rawn-Schatzinger

1987 McDonald Site-41HI105 (X41HI171). In Archeology at Aquilla Lake: 1978-1982 Investigations, Volume 1, compiled by D. O. Brown, pp. 38-1 to 38-145. Research Report No. 81. Texas Archeological Survey, University of Texas at Austin.

Bruseth, J. E., and N. A. Kenmotsu

1991 Soldiers of Misfortune: The de Soto Expedition Through Texas. Heritage 9(4):1217.

Bruseth, J. E., and W. A. Martin

1987 The Wylie Focus: Cultural Reality or Archaeological Myth. In The Bird Point Island and Adams Ranch Sites: Methodological and Theoretical Contributions to North Central Texas Archaeology, edited by J. E. Bruseth and W. A. Martin, pp. 267284. Richland Creek Technical Series, vol. II. Archaeology Research Program, Southern Methodist University, Dallas.

Burson, E. A., and M. B. Cliff

1999 Cultural Resources Survey of the Proposed Environmental Restoration Areas Along The Old West Fork of the Trinity River, Dallas County, Texas. Miscellaneous Reports of Investigations Number 196. Geo-Marine, Inc., Plano, Texas. 
Burson, E. A., S. M. Hunt, D. E. Peter, and D. Shanabrook

1999 Cultural Resources Survey of the Proposed West Fork Relief Interceptor, WF-11B, Tarrant and Dallas Counties, Texas. Miscellaneous Reports of Investigations Number 190. Geo-Marine, Inc., Plano, Texas.

Chipman, D. E.

1992 Spanish Texas 1519-1821. University of Texas Press, Austin.

City of Haltom City

1997 Chamber of Commerce, History of Haltom City. Web Page. City of Haltom City, Texas.

Cliff, M. B., D. E. Peter, S. M. Hunt, D. Shanabrook, T. Carter, and V. Green

1996 Archeological Evaluation of the Harbor Pointe Site (41DL369) Dallas County, Texas. Miscellaneous Reports of Investigations Number 120. Geo-Marine, Inc., Plano, Texas.

Crook, W. W., Jr., and R. K. Harris

1952 Trinity Aspect of the Archaic Horizon: Carrollton and Elam Foci. Bulletin of the Texas Archeological Society 23:7-38.

1954 Traits of the Trinity Aspect Archaic: Carrollton and Elam Foci. The Record 12(1):216.

1957 Hearths and Artifacts of Early Man near Lewisville, Texas, and Associated Faunal Material. Bulletin of the Texas Archeological Society 28:7-79.

1958 A Pleistocene Campsite near Lewisville, Texas. American Antiquity 23:233-246.

1961 Significance of a New Radiocarbon Date from the Lewisville Site. Bulletin of the Texas Archeological Society 32:327-330.

Dawson, C. L., and T. L. Sullivan

1973 Excavations at Lake Lavon: 1969. Report No. 25. Archaeology Research Program, Southern Methodist University, Dallas. Submitted to the National Park Service.

Edwards, S. K., and D. E. Peter

1991 Archeological Assessment of the Potential Impacts of the Forest Park Parking Lot Alternative on Site 41TR119, Fort Worth, Texas. Miscellaneous Report of Investigations No. 27. Geo-Marine, Inc., Plano, Texas.

Ferring, C. R.

1989 The Aubrey Clovis Site: A Paleoindian Locality in the upper Trinity River basin, Texas. Current Research in the Pleistocene 6:9-11.

1990 Late Quaternary Geology and Geoarcheology of the Upper Trinity River Drainage Basin, Texas. Field Trip No. 11 Guidebook. Annual Meeting of the Geological Society of America, Dallas. 
1994 An Archaeological survey of Trinity River Linear Park, Tarrant County, Texas. Geoarch Consultants, Denton, Texas.

Ferring, C. R (with contributions by S. A. Elias, S. A. Hall, H. Haas, J. D. Humphrey, E. L. Lundelius, Jr., R. W. Neck, and B. C. Yates)

2001 The Archaeology and Paleoecology of the Aubrey Clovis Site (41DN479), Denton County, Texas. Center for Environmental Archaeology, Department of Geography, University of North Texas, Denton.

Ferring, C. R., and J. A. Byers

1996 Archaeological and Geologic Investigations at the Metrovest Development, Tarrant County, Texas. Unpublished draft report. Geoarch Consultants, Denton, Texas.

Ferring, C. R., and N. Reese

1980 Archaeological Investigations at Four Historical Sites with the Lakeview Reservoir Area, Dallas County, Texas. Draft report submitted to U.S. Army Corps of Engineers, Fort Worth District.

Ferring, C. R., and B. C. Yates (with contributions by H. Gill-King and K. Brown)

1997 Holocene Geoarcheology and Prehistory of the Ray Roberts Lake Area, North Central Texas. Institute of Applied Sciences, University of North Texas, Denton.

Ferring, C. R., and B. C. Yates (with contributions by K. L. Brown and M. E. Brown)

1998 Archaeological Investigations at Five Prehistoric Sites at Lewsiville Lake, Denton County, Texas. Center for Environmental Archaeology, Institute of Applied Sciences, University of North Texas, Denton.

Fox, D. E.

1979 An Archeological Reconnaissance of Outfall Sewer Proposed for Haltom City, Tarrant County, Texas. Department of Construction Grants and Water Quality Planning, Haltom City, Texas.

Fritz, G. C.

1993 Archeobotanical Evidence from the Cobb-Pool Site, A Late Prehistoric Farmstead in Dallas County, Texas. Bulletin of the Texas Archeological Society 64:227-246.

Garrett, J. K.

1972 Fort Worth: A Frontier Triumph. Encino Press, Austin.

Harris, R. K., and I. M. Harris

1970 A Bison Kill on Dixon's Branch, Site 27A2-5, Dallas County, Texas. The Record 27(1):1-2.

Herz, N.

1990 Stable Isotope Geochemistry Applied to Archaeology. In Archaeological Geology of North America, edited by N. P. Lasca and J. Donahue, pp. 585-595. Centennial Special Volume 4. Geological Society of America, Boulder, Colorado. 
Hofman, J. L.

1989a Prehistoric Culture History-Hunters and Gatherers in the Southern Great Plains. In From Clovis to Comanchero: Archeological Overview of the Southern Great Plains, by J. L. Hofman, R. L. Brooks, J. S. Hays, D. W. Owsley, R. L. Jantz, M. K. Marks, and M. H. Manhein, pp. 25-60. Research Series No. 35. Arkansas Archeological Survey, Fayetteville.

1989b Protohistoric Culture History on the Southern Great Plains. In From Clovis to Comanchero: Archeological Overview of the Southern Great Plains, by J. L. Hofman, R. L. Brooks, J. S. Hays, D. W. Owsley, R. L. Jantz, M. K. Marks, and M. H. Manhein, pp. 91-100. Research Series No. 35. Arkansas Archeological Survey, Fayetteville.

Hofman, J. L., R. L. Brooks, J. S. Hays, D. W. Owsley, R. L. Jantz, M. K. Marks, and M. H. Manhein

1989 From Clovis to Comanchero: Archeological Overview of the Southern Great Plains. Research Series No. 35. Arkansas Archeological Survey, Fayetteville.

Hudson, C. M.

1986 Hernando de Soto in the Caddo Area. Paper presented at the 28th Caddo Conference, Little Rock, Arkansas.

Hunt, S. M., D. E. Peter, and D. K. Sheppard

1993 Phase II Cultural Resources Assessment of Railtran Commuter Line South Irving Transit Station to Station 130+00, Dallas and Tarrant Counties, Texas. Miscellaneous Report of Investigations No. 47. Geo-Marine, Inc., Plano, Texas.

Jelks, E. B. (editor)

1967 The Gilbert Site: A NorteZo Focus Site in Northeastern Texas. Bulletin of the Texas Archeological Society, Volume 37 (for 1966).

Jensen, H. P., Jr.

1968 Report on Excavations at the Field Ranch Site (X41CO10), Cooke County, Texas. Bulletin of the Texas Archeological Society 39:133-146.

John, E. A. H.

1975 Storms Brewed in Other Men's Worlds: The Confrontation of Indians, Spanish, and French in the Southwest, 1540-1795. University of Nebraska Press, Lincoln.

Johnson, L., Jr.

1989 Great Plains Interlopers in the Eastern Woodlands During Late Paleo-Indian Times: The Evidence from Oklahoma, Texas, and Areas Close By. Report No. 36. Office of the State Archeologist, Texas Historical Commission, Austin.

Johnson, R. E.

1956 Report on Site T-5 in Tarrant County. The Catalogue of the Tarrant County Archeological Society 1 (Section 2):2-5. 
Jurgens, C. J.

1982 Archeological Reconnaissance of Revised Pipeline Alignment, Big Bear Creek Interceptor, Trinity River Authority, Tarrant County, Texas. Texas Department of Water Resources, Austin.

Jurney, D. H., S. A. Lebo, and M. M. Green (compilers)

1988 Historic Farming on the Hogwallow Prairies: Ethnoarcheological Investigations of the Mountain Creek Area, North Central Texas. Joe Pool Lake Archaeological Project, Vol. II. Archaeology Research Program, Southern Methodist University, Dallas.

Krapf, K. A., and S. M. Hunt

1996 Cultural Resources Survey of the Proposed Villages of Fossil Creek Housing Development, City of Fort Worth, Tarrant County, Texas. Miscellaneous Report of Investigations No. 143. Geo-Marine, Inc., Plano, Texas.

Krieger, A. D.

1946 Culture Complexes and Chronology in Central Texas with Extension of Puebloan Dating to the Mississippi Valley. Publication No. 4640. University of Texas, Austin.

1947 The Eastward Extension of Puebloan Datings toward Cultures of the Mississippi Valley. American Antiquity 12(3):141-148.

Largent, F. B., Jr., S. M. Hunt, and D. E. Peter

1994 Cultural Resources Investigations at the East First Street Bridge, Fort Worth, Tarrant County, Texas. Draft report. Submitted to Rady and Associates, Engineers, Fort Worth, Texas. Miscellaneous Report of Investigations No. 74. Geo-Marine, Inc., Plano, Texas.

Lebo, S. A., and K. L. Brown

1990 Archaeological Survey of the Lewisville Lake Shoreline, Denton County, Texas. Institute of Applied Sciences, University of North Texas, Denton.

Lorrain, D., and N. Hoffrichter

1968 The Lower Rockwall Site, Rockwall County, Texas. Salvage Project. Southern Methodist University, Dallas. Submitted to the National Park Service.

Lynott, M. J.

1975 Archaeological Excavations at Lake Lavon 1974. Contribution in Anthropology No. 16. Archaeology Research Program, Southern Methodist University, Dallas.

1977 A Regional Model for Archaeological Research in Northcentral Texas. Ph.D. dissertation, Department of Anthropology, Southern Methodist University, Dallas.

Lynott, M. J., T. W. Boutton, J. E. Price, and D. E. Nelson

1986 Stable Carbon Isotopic Evidence for Maize Agriculture in Southeast Missouri and Northeast Arkansas. American Antiquity 51(1):51-65. 
McCormick, O. F.

1976 Archaeological Survey Proposed Wastewater Interceptor Route, Haltom City, Texas. North Texas State University for Rady and Associates, Inc., Denton.

McGregor, D. E.

1988 Archaeological Background. In Late Holocene Prehistory of the Mountain Creek Drainage, edited by D. E. Peter and D. E. McGregor, pp. 27-33. Joe Pool Lake Archaeological Project, Vol. I. Archaeology Research Program, Southern Methodist University, Dallas.

McMahan, C.A., R. G. Frye, and K. L. Brown

1984 The Vegetation Types of Texas. Wildlife Division, Texas Parks and Wildlife Department, Austin.

Meltzer, D. J.

1987 The Clovis Paleoindian Occupation of Texas: Results of the Texas Clovis Fluted Point Survey. Bulletin of the Texas Archeological Society 57:27-68.

Meltzer, D. J., and M. R. Bever

1995 Paleoindians of Texas: An Update on the Texas Clovis Fluted Point Survey. Bulletin of the Texas Archeological Society 66:47-81.

Meltzer, D. J., and B. D. Smith

1986 Paleoindian and Early Archaic Subsistence Strategies in Eastern North America. In Foraging, Collecting and Harvesting: Archaic Period Subsistence and Settlement in the Eastern Woodlands, edited by S. W. Neusius, pp. 3-31. Occasional Paper No. 6. Center for Archaeological Investigations, Southern Illinois University, Carbondale.

Morgan, L. W.

1975 An Empirical Analysis of a Pre-Neo-American Site in Dallas County, Texas. Unpublished Master's thesis, Department of Anthropology, University of Texas at Arlington.

Morris, V., and B. Morris

1970 Excavation of Bison Remains in Northwest Dallas County. The Record 27(1):2-5.

Newcomb, W. W., Jr.

1993 Historic Indians of Central Texas. Bulletin of the Texas Archeological Society 64:163.

Peter, D. E., and V. G. Clow (editors)

1999 An Archeological and Osteological Investigation of 41DL373, Spring Creek Park Preserve, Dallas County, Texas. Miscellaneous Reports of Investigations No. 186. Submitted to Dallas County Parks and Open Spaces Program. Geo-Marine, Inc., Plano, Texas. 
Peter, D. E., B. Ellwood, J. Schieber, and B. Yates

1987 Test Excavations of the River Bend Site (41TR68). Center for Geoarcheological Studies, University of Texas at Arlington.

Peter, D. E., and S. Gaither

1990 Archeological Survey of the Proposed Northeast Neighborhood/Community Park, Arlington, Texas. Miscellaneous Reports of Investigations No. 16. Geo-Marine, Inc., Plano, Texas.

Peter, D. E., and D. E. McGregor (editors)

1988 Late Holocene Prehistory of the Mountain Creek Drainage. Joe Pool Lake Archaeological Project, Vol. I. Archaeology Research Program, Southern Methodist University, Dallas.

Petermann, A.

1872 Map of Texas, Indian Territory, Louisiana, Arkansas, Missouri, Kansas. Gotha.

Prewitt, E. R.

1981 Cultural Chronology in Central Texas. Bulletin of the Texas Archeological Society 52:65-89.

1985 From Circleville to Toyah: Comments on Central Texas Chronology. Bulletin of the Texas Archeological Society 54 (for 1982):201-238.

Prikryl, D. J.

1987 A Synthesis of Prehistory on the Lower Elm Fork of the Trinity River. Unpublished Master's thesis, University of Texas, Austin.

1990 Lower Elm Fork Prehistory: A Redefinition of Cultural Concepts and Chronologies along the Trinity River, North Central Texas. Report 37. Office of the State Archeologist, Texas Historical Commission, Austin.

1993 Introduction to Section III: Regional Preservation Plan for Archeological Resources, Prairie-Savanna Archeological Region. In Archeology in the Eastern Planing Region, Texas: A Planning Document, edited by N. A. Kenmotsu and T. K. Perttula, pp. 191-204. Cultural Resource Management Report 3. Department of Antiquities Protection, Texas Historical Commission, Austin.

Raab, L. M., A. J. McIntyre, J. Bruseth, D. McGregor, C. Ferring, and N. Reese

1982 Archaeological Investigations at Lakeview Lake, 1979 and 1980. Archaeological Monographs 2. Archaeological Research Program, Southern Methodist University, Dallas.

Raab, L. M., and A. I. Woosley

1982 A Terrace Habitat and Late Prehistoric Settlement in Northern Texas: Pollen and Geological Evidence. Plains Anthropologist 27(97):185-192. 
Ray, T.

1965 The History of Birdville. Fort Worth.

Ressel, D. D.

1981 Soil Survey of Tarrant County, Texas. U.S. Department of Agriculture, Soil Conservation Service, Washington, D.C.

Rohn, A. H.

1998 Haley's Point (34MA15) on the Red River, Marshall County, Oklahoma (Area F). Publications in Anthropology No. 4. Wichita State University, Wichita, Kansas.

Rose, J. C., and M. P. Hoffman

1989 Maize Dependency in the Trans-Mississippi South. Paper presented at the 31st Annual Caddo Conference, Norman, Oklahoma, March 3-5.

Ross, R. E.

1966 The Upper Rockwall and Glen Hill Sites, Forney Reservoir, Texas. Papers No. 9. Texas Archeology Salvage Project, University of Texas, Austin.

Schambach, F. F.

1989 The End of the Trail: The Route of Hernando de Soto's Army through Southwest Arkansas and East Texas. The Arkansas Archeologist 27/28(for 1986 and 1987):933.

Sergeant, G. W.

1953 Early History of Tarrant County. Master’s thesis, University of Texas, Austin.

Shafer, H. J.

1977 Early Lithic Assemblages in Eastern Texas. The Museum Journal 17:187-197. West Texas Museum Association, Lubbock.

Shaunessy, K. J., D. H. Jurney, and J. L. Yedlowski

1994 A Cultural Resource Reconnaissance Survey of the Metrovest Mining and Development Project Area, Tarrant County, Texas. Unpublished draft report. Report of Investigations No. 1. Archaeology Research Program of the Mercyhurst Archaeological Institute, Mercyhurst College, DeSoto, Texas.

Skinner, S. A.

1997 Archaeology of the Arcadia Park North, Tarrant County, Texas. AR Consultants, Dallas.

Skinner, S. A., and L. Baird (assemblers)

1985 Archaeology and History of Lake Ray Roberts, Volume III: Settlement in a Marginal Zone. AR Consultants, Dallas.

Skinner, S. A., S. C. Caran, B. B. Whorton, and L. K. Trask

1997 Cultural Resources Evaluation from the Trantula Bridge to White Settlement, Fort Worth, Texas. Cultural Resources Report 97-19. AR Consultants, Dallas. 
Skinner, S. A., M. B. Cliff, L. Baird, A. B. Emerson, Jr., J. Bennett, A. R. Faust, J. Kaskey, K. Ladder, M. D. Northern, A. Pitchfork, J. Rally, D. G. Chateaus, and D. Shanabrook

1982 The Archaeology and History of Lake Ray Roberts, Volume 2: Construction Area Testing. Cultural Resources Report 82-9. Environmental Consultants, Inc., Dallas.

Skinner, S. A., and D. T. Connors

1979 Archaeological Investigations at Lakeview Lake. Research Report 118. Archaeology Research Program, Southern Methodist University, Dallas.

Skinner, S. A., and B. B. Whorton

1993 Archaeological Survey of Arcadia Trail Park, Tarrant County, Texas. Cultural Resources Report 93-7. AR Consultants, Dallas.

Slaughter, E. H., and B. R. Hoover

1963 Sulphur River Formation and the Pleistocene Mammals of the Ben Franklin Local Fauna. Journal of the Graduate Research Center 31(3):132-148. Southern Methodist University, Dallas.

Smith, F. T.

1996 The Caddos, the Wichitas, and the United States, 1846-1901. Texas A\&M University Press, College Station.

Sollberger, J. B.

1953 The Humphrey Site. The Record 11(3):11-14.

Stanford, D.

1981 Who’s On First? Science 81 2(5):91-92.

Stephenson, R. L.

1949 Archaeological Survey of Benbrook Reservoir, Tarrant County, Texas. River Basin Surveys, Austin Office, Smithsonian Institution.

1952 The Hogge Bridge Site and the Wylie Focus. American Antiquity 17:299-312.

Story, D. A.

1985 Adaptive Strategies of Archaic Cultures of the West Gulf Coastal Plain. In Prehistoric Food Production in North America, edited by R. I. Ford, pp. 19-56. Anthropological Papers No. 75. Museum of Anthropology, University of Michigan, Ann Arbor.

1990 Cultural History of the Native Americans. In The Archeology and Bioarcheology of the Gulf Coastal Plain, 2 vols., by D. A. Story, J. A. Guy, B. A. Burnett, M. D. Freeman, J. C. Rose, D. G. Steele, B. W. Olive, and K. J. Reinhard, pp. 1:163-1:366. Research Series No. 38. Arkansas Archeological Survey, Fayetteville. 
Story, D. A., J. A. Guy, B. A. Burnett, M. D. Freeman, J. C. Rose, D. G. Steele, B. W. Olive, and K. J. Reinhard

1990 The Archeology and Bioarcheology of the Gulf Coastal Plain. 2 vols. Research Series No. 38. Arkansas Archeological Survey, Fayetteville.

Street, S.

1893 Sam Street's Map of Tarrant County, Texas. Reproductions available from the Dallas County Historical Society.

Trask, L. K., and B. B. Whorton

1995 Cultural Resources Survey of Big Fossil Creek Greenbelt, Haltom City, Texas. AR Consultants, Inc. Dallas.

Trask, L. K., B. B. Whorton, and S. A. Skinner

1995 Archaeological Survey of the West Fork Relief Interceptor, Grand Prairie, Texas. AR Consultants, Dallas.

van der Merwe, N. J., and J. Vogel

1977 Isotopic Evidence for Early Maize Cultivation in New York State. American Antiquity 42:238-242.

Vehik, S. C.

1994 Cultural Continuity and Discontinuity in the Southern Prairies and Cross Timbers. In Plains Indians, A.D. 500-1500: The Archaeological Past of Historic Groups, edited by K. H. Schlesier, pp. 239-263. University of Oklahoma Press, Norman.

Webb, W. P., and H. B. Carroll (editors)

1952 The Handbook of Texas. 2 vols. Texas State Historical Association, Austin.

Weber, D. J.

1992 The Spanish Frontier in North America. Yale University Press, New Haven.

Weddle, R. S.

1964 The San Sabá Mission: Spanish Pivot in Texas. University of Texas Press, Austin.

1965 The San Sabá Mission: Approach to the Great Plains. Great Plains Journal 4(2):2938.

Werdman, C.

1969 Arlington, Texas . . Y Youngest City X Oldest History. Werdman Publications, Arlington.

Whitsett, W. H.

1976 Archeological Survey of the Proposed Rush Creek Interceptor, Arlington, Tarrant County, Texas. Texas Water Quality Board, Austin. 
Whitsett, W. H., and D. E. Fox

1979 An Archeological Reconnaissance of the Big Bear Creek Interceptor, Trinity River Authority, Grapevine, C-48-1189-01. Texas Department of Water Resources, Austin.

1980 An Archeological Reconnaissance at the Colleyville, Tarrant County, Texas, C-481144. Texas Department of Water Resources, Austin.

Whorton, B. B., and S. A. Skinner

1995 Cultural Resources Survey of Arcadia Park South, Tarrant County, Texas. AR Consultants, Inc., Dallas.

Yates, B. C., and C. R. Ferring (editors)

1986 An Assessment of the Cultural Resources in the Trinity River Basin, Dallas, Tarrant, and Denton Counties, Texas. Institute of Applied Sciences, North Texas State University, Denton. Submitted to the U.S. Army Corps of Engineers, Fort Worth District. 
Predictive Model for Archeological and Historic Site Locations: Big Fossil Creek Drainage, Tarrant County, Texas 